\title{
CONCISE REVIEW OF MECHANISMS OF BACTERIAL ADHESION TO BIOMATERIALS AND OF TECHNIQUES USED IN ESTIMATING BACTERIA- MATERIAL INTERACTIONS
}

\author{
M. Katsikogianni and Y.F. Missirlis* \\ Laboratory of Biomechanics and Biomedical Engineering, Department of Mechanical Engineering, University of \\ Patras, Patras, Greece
}

\begin{abstract}
This article reviews the mechanisms of bacterial adhesion to biomaterial surfaces, the factors affecting the adhesion, the techniques used in estimating bacteria-material interactions and the models that have been developed in order to predict adhesion. The process of bacterial adhesion includes an initial physicochemical interaction phase and a late molecular and cellular one. It is a complicated process influenced by many factors, including the bacterial properties, the material surface characteristics, the environmental factors, such as the presence of serum proteins and the associated flow conditions. Two categories of techniques used in estimating bacteria-material interactions are described: those that utilize fluid flowing against the adhered bacteria and counting the percentage of bacteria that detach, and those that manipulate single bacteria in various configurations which lend themselves to more specific force application and provide the basis for theoretical analysis of the receptor-ligand interactions. The theories that are reviewed are the Derjaguin-LandauVerwey-Overbeek (DLVO) theory, the thermodynamic approach and the extended DLVO theory. Over the years, significant work has been done to investigate the process of bacterial adhesion to biomaterial surfaces, however a lot of questions still remain unanswered.
\end{abstract}

Key Words: Bacterial adhesion, surface chemistry, surface topography, biomaterial-bacterial interactions, radial flow device.

*Address for correspondence:

Y.F. Missirlis

Laboratory of Biomechanics and Biomedical Engineering, Department of Mechanical Engineering

University of Patras, Patras, Greece

FAX Number: +302610997249

E-mail: misirlis@mech.upatras.gr
Infection remains a major impediment to the long-term use of many implanted or intravascular devices such as joint prostheses, heart valves, vascular catheters, contact lenses and dentures (Geesey, 2001; von Eiff et al., 2002; Vincent, 2003; Lejeune, 2003). Frequently, failure of such devices stems from bacterial biofilm build up (Peters et al., 1982; Chang and Marritt, 1992; Morra and Cassinelli, 1996; An and Friedman, 1998) which is extremely resistant to host defense mechanisms (Gray et al., 1984) and antibiotic treatment (Duguid et al., 1992). Often the only solution to an infected implanted device is its surgical removal.

Bacterial adhesion to biomaterial surfaces is the essential step in the pathogenesis of these infections, however the molecular and physical interactions that govern bacterial adhesion to biomaterials have not been understood in detail. Both specific and non-specific interactions may play an important role in the ability of the cell to attach to (or to resist detachment from) the biomaterial surface (Vaudaux et al., 1990; Heilmann et al., 1996; Morra and Cassinelli, 1997; An and Friedman, 1998). The relative contributions of specific and nonspecific mechanisms are likely to depend on the surface properties of the biomaterial as well as the associated flow conditions.

Data taken from the National Nosocomial Infections Surveillance System (von Eiff et al., 2002; Vincent, 2003) showed that nosocomial infections affect approximately $10 \%$ of all in-patients, delay discharge by average of 11 days, cost 2,8 times no infection and direct cause 5000 deaths/year in England. Moreover, it has been shown that Coagulase Negative Staphylococci (CoNS) are the most commonly reported pathogens $(37.3 \%$, compared with $12.6 \%$ for Staphylococcus aureus) isolated from bloodstream infections in intensive care unit patients and are becoming increasingly important, especially as causes of hospital-acquired infections. Paragioudaki et al. (2004) showed that a cocktail of bacteria and fungi are present in most infection sites and their relative contribution depends on the host material, among other factors (Table 1).

These bacteria are normal inhabitants of human skin and, therefore, one of the major challenges of daily diagnostic work is to distinguish clinically significant strains from contaminant strains. Most important in the pathogenesis of foreign-body-associated infections is the ability of these bacteria to colonize the polymer surface by the formation of a thick, multilayered biofilm (Christensen et al., 1994).

Bacterial adhesion to a material surface can be described as a two-phase process including an initial, 
Table 1. Microorganisms isolated from intravenous catheter-related infections of patients located in different hospital wards

\begin{tabular}{|c|c|c|c|c|c|c|c|c|c|c|}
\hline \multirow{2}{*}{$\begin{array}{l}\text { Organisms } \\
\text { isolated }\end{array}$} & \multicolumn{5}{|c|}{ CRBSI } & \multicolumn{5}{|c|}{ C/PVC-BSI } \\
\hline & GS & IM & ICUa & ICUn & $\begin{array}{l}\text { Total } \\
(\%)\end{array}$ & GS & IM & ICUa & ICUn & $\begin{array}{l}\text { Total } \\
(\%)\end{array}$ \\
\hline CNS & 37 & 34 & 14 & 7 & $\begin{array}{l}92 \\
(59.4)\end{array}$ & 16 & 17 & 16 & 1 & $50(48)$ \\
\hline $\begin{array}{l}\text { Staphylococcus } \\
\text { aureus }\end{array}$ & 1 & 7 & - & - & $8(5.1)$ & 1 & 1 & - & - & $2(2)$ \\
\hline Enterococci & 1 & 3 & - & - & $4(2.6)$ & 4 & 3 & - & - & $7(6.7)$ \\
\hline Streptococci & - & - & - & - & - & 1 & 3 & - & - & $4(3.9)$ \\
\hline $\begin{array}{l}\text { Pseudomonas } \\
\text { aeruginosa }\end{array}$ & 7 & 3 & 9 & - & $\begin{array}{l}19 \\
(12.3)\end{array}$ & 4 & 3 & 13 & - & $\begin{array}{l}20 \\
(19.2)\end{array}$ \\
\hline $\begin{array}{l}\text { Other Gram- } \\
\text { negatives }{ }^{b}\end{array}$ & 15 & 3 & 4 & 2 & $\begin{array}{l}24 \\
(15.5)\end{array}$ & 3 & 5 & 4 & 1 & $\begin{array}{l}13 \\
(12.5)\end{array}$ \\
\hline Fungi & 3 & 4 & - & 1 & $8(5.1)$ & 2 & 3 & 2 & 1 & $8(7.7)$ \\
\hline Total (\%) & \begin{tabular}{|l|}
64 \\
$(41.3)$
\end{tabular} & $\begin{array}{l}54 \\
(34.8)\end{array}$ & $\begin{array}{l}27 \\
(17.4)\end{array}$ & $10(6.5)$ & $\begin{array}{l}155 \\
(100)\end{array}$ & $\begin{array}{l}31 \\
(29.8)\end{array}$ & $\begin{array}{l}35 \\
(33.6)\end{array}$ & $\begin{array}{l}35 \\
(33.6)\end{array}$ & $3(3)$ & $\begin{array}{l}104 \\
(100)\end{array}$ \\
\hline \multicolumn{11}{|c|}{$\begin{array}{l}{ }^{a} \text { Hospital wards: GS: General Surgery; IM: Internal Medicine; ICUa: Intensive Care Unit for adults; ICUn: } \\
\text { Intensive Care Unit for neonates. }\end{array}$} \\
\hline \multicolumn{11}{|c|}{${ }^{5}$ Gram-negative bacilli, other than $P$. aeruginosa. } \\
\hline
\end{tabular}

Data taken from Paragioudaki et al. (2004)

instantaneous and reversible physical phase (phase one) followed by a time-depended and irreversible molecular and cellular phase (phase two) (An and Friedman, 1998). The factors involved in both phases of bacterial adhesion as well as the techniques and theories used to study this adhesion are reviewed in this article.

While this mini review relates to bacteria in general, more emphasis is given to S. epidermidis.

\section{Types of infections}

The most important group of particularly susceptible patients for infection comprises those with indwelling or implanted foreign polymer bodies (Christensen et al., 1994; Tacconelli et al., 1997; Raad, 1998; Scierholz and Beuth, 2001) and immunocompromised patients, such as premature babies (Pessoa-Silva et al., 2001) and patients hospitalized for chemotherapy, other malignant diseases or organ transplantation (Pagano et al., 1997; Souvenir et al., 1998). The most common bacteria that are diagnosed are Coagulase Negative Staphylococci (CoNS), particularly S. epidermidis (slime positive), S. aureus, Pseudomonas aeruginosa, E.coli, Streptococci and Candida species (Diekema et al., 2001). Depending on the kind of device, its insertion side and the duration of the insertion, different syndromes generate several clinical presentations.

Furthermore, there is growing evidence that other, more chronic, polymer-associated clinical syndromes may also be at least partly associated with CoNS, particularly with S. epidermidis (Huebner and Goldmann, 1999). These syndromes include the aseptic loosening of hip or other joint prostheses (Perdreau-Remington et al., 1996) and late-onset endophthalmitis after implantation of artificial intraocular lenses after cataract surgery (Jansen et al., 1991; Garcia-Saenz et al., 2000; Willcox et al., 2001). There are also reports of endocarditis (Miele et al., 2001), urinary track infections (Trautner et al., 2004) and wound infections (Merriam et al., 2003) that are caused by $S$. epidermidis and there is no particular evidence that $S$. epidermidis can cause these diseases in the absence of a foreign body. Table 2 shows these diseases that are caused by implanted devices (Gottenbos et al., 2002).

Table 2. Types and frequency of infections

\begin{tabular}{c|c}
\hline Urinary tract: & UT catheters: $10-20 \%$ \\
\hline Percutaneous: & CV catheters: $4-12 \%$ \\
\hline & Short indwelling catheters: $0,5-3 \%$ \\
\hline & Temporary pacemaker: $4 \%$ \\
\hline Subcutaneous: & Peritoneal dialysis catheters: $3-5 \%$ \\
\hline Soft Tissue: & Cardiac pacemaker: $1 \%$ \\
\hline Circulatory system: & Mammary prosthesis: $1-7 \%$ \\
\hline & Intraocular lenses: $0.13 \%$ \\
\hline & Prosthetic heart valve: $1.88 \%$ \\
\hline & Multiple heart valve: $3.6 \%$ \\
\hline Bones: & Vascular graft: $1.5 \%$ \\
\hline & Artificial heart $40 \%$ \\
\hline & Prosthetic hip: $2.6-4.0 \%$ \\
\hline
\end{tabular}




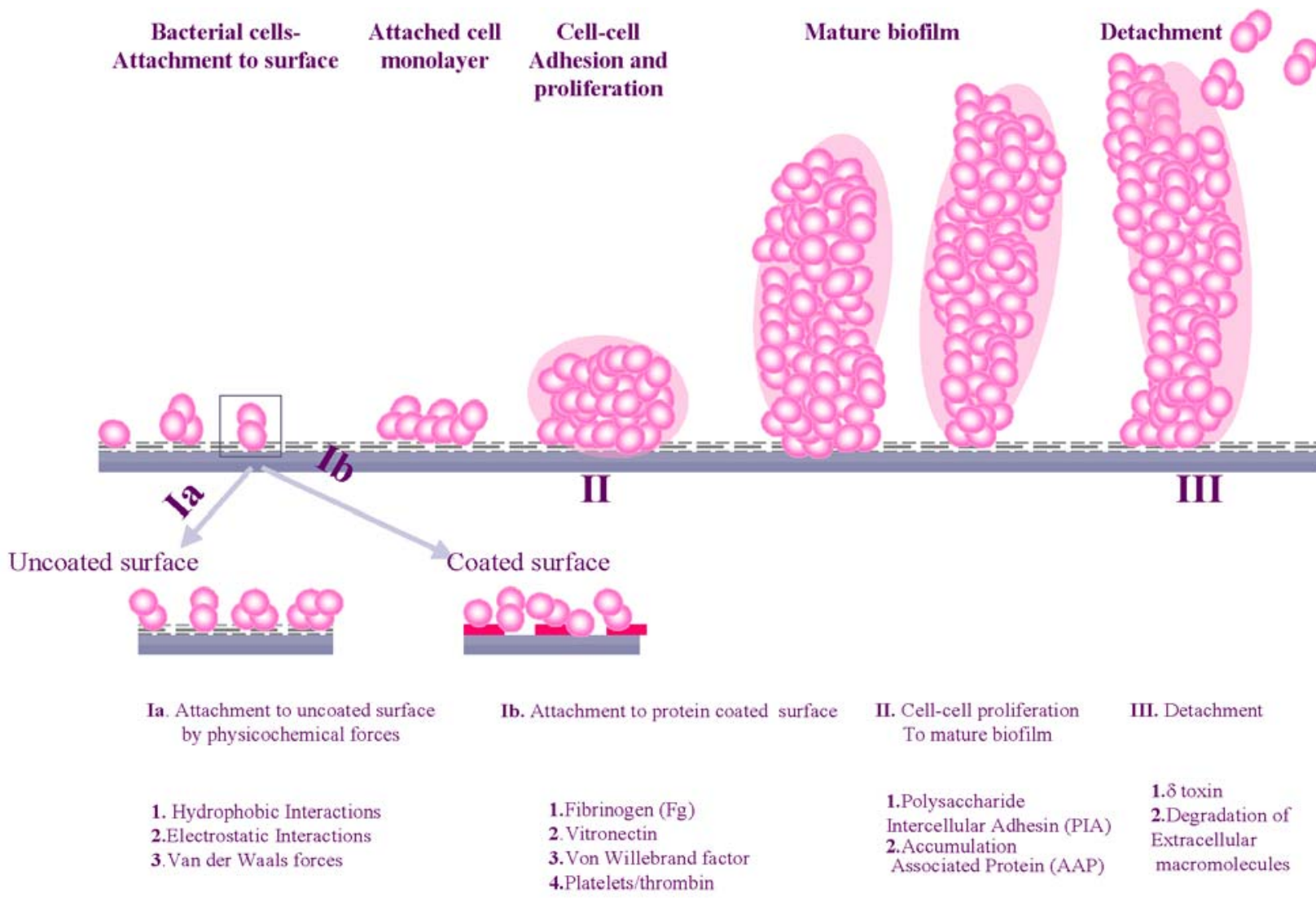

Figure 1. Schematic model of the phases involved in S. epidermidis biofilm formation formation and bacterial factors involved. Modified from Vuong and Otto (2002).

\section{Pathogenesis of polymer-associated infection}

S. epidermidis does not produce many toxins and tissue damaging exoenzymes, as does $S$. aureus but the success of S.epidermidis as a pathogen has to be attributed to its ability to adhere to surfaces and to remain there, under the cover of a protecting extracellular material, forming a biofilm (Rupp and Archer, 1994; Fletcher and Decho, 2001 web reference; Vuong and Otto, 2002).

Small numbers of bacteria from the patient's skin or mucous membranes, where these bacteria normally occur, probably contaminate the polymer during the surgical implantation of the device. Sometimes the bacteria are acquired from the hands of the surgical or the clinical staff, from contaminated disinfectants, from the hospital environment-other patients or from distant local infections (Maki et al., 1997). Since the bacteria rapidly adhere to polymer material, they start to proliferate to form multilayered cell clusters on the polymer surface, which are embedded in extracellular material as it is shown in Figure 1. An accumulated biomass of bacteria and their extracellular material (slime) on a solid surface is called biofilm ( $\mathrm{O}$ 'Toole et al., 2000). After biofilm establishment, non-adherent and some adherent daughter cells escape from the slime layer, either by switching off slime production through a mechanism of phenotypic modulation, or by exhaustion conditions that support slime production, and are then free to drift to new colonization sites to repeat the colonization process. Moreover $\delta$-toxin, the only toxin $S$. epidermidis produces, causes, not only lysis of erythrocytes, but acts also as a detergent that constructs biofilm structure and helps in detachment.

The slime produced by CoNS is a loose hydrogel of polysaccharides associated through ionic interactions. The polysaccharides are composed of neutral monoposaccharides including d-glucose, d-galactose, $\mathrm{d}$ mannosse, 1-fucose, and 1-rhamnose and of amino sugars, polyols and uronic acid (Karamanos et al., 1995).

Bacterial strains that do not produce slime are less adherent and less pathogenic. The current concept is that the production of slime is especially important for events after the initial phase of adhesion, which include colonization of various surfaces, protection against phagocytosis, interference with the cellular immune response and reduction of antibiotic effects (Costerton, 1999; Costerton et al., 1999). Bacteria that do not adhere quickly to the surfaces are rapidly killed by the immune system. Slime-forming bacteria are less susceptible to vancomycin and other antibiotics after they are adhered to biomaterials than bacteria grown in culture. Such antibiotic resistance may be partly due to the slow growth rate of bacteria in the biofilm or to the limited transport of nutrients, metabolites, and oxygen to and from the biofilm surface (Duguid et al., 1992; Mah and O'Toole, 2001; Stewart and Costerton, 2001; Donlan and Costerton, 2002; Monzon et al., 2002). Moreover, biofilm protects bacteria from detachment due to flow conditions (Donlan and Costerton, 2002). Chronic infections occur when a bacterial inoculum reaches critical size and overcomes the local host defences. 


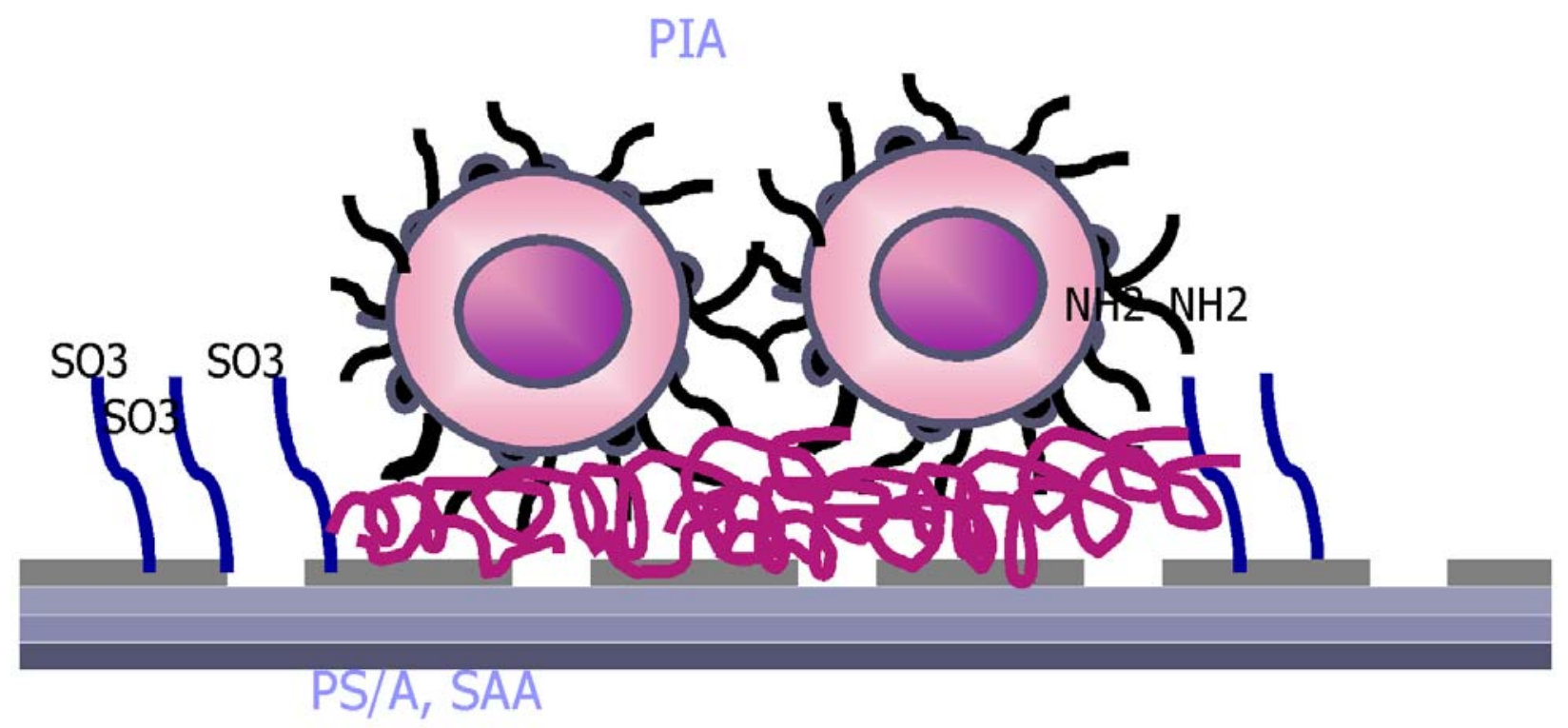

$\mathrm{Fg}$

Figure 2. Schematic model of phase 2.

\section{Physicochemical interactions between bacteria and surfaces: Phase one}

Bacterial adhesion to surfaces consists of the initial attraction of the cells to the surface followed by adsorption and attachment (Rijnaarts et al., 1995). Generally bacteria prefer to grow on available surfaces rather than in the surrounding aqueous phase. Bacteria move to or are moved to a material surface through and by the effects of physical forces, such as Brownian motion, van der Waals attraction forces, gravitational forces, the effect of surface electrostatic charge and hydrophobic interactions (Gottenbos et al., 2002), while chemotaxis and perhaps haptotaxis contribute to this process (Kirov, 2003). Bacterial movement can be directed by concentration grantients of diffusible ("chemotaxis") or surface bound ("haptotaxis") chemical factors referred to as chemoattractants (e.g. amino acids, sugars, oligopeptides). Chemotaxis occurs in almost all microbes and can modulate bacterial growth on surfaces by regulating cellular adhesion components and preparing cells for cellcell and cell-surface interactions (Jenal, 2004).

The physical interactions are further classified as longrange interactions and short-range interactions (Gottenbos et al., 2002). The long-range interactions (nonspecific, distances $>50 \mathrm{~nm}$ ) between cells and surfaces are described by mutual forces, which are a function of the distance and free energy. Short-range interactions become effective when the cell and the surface come into close contact $(<5$ $\mathrm{nm}$ ), these can be separated into chemical bonds (such as hydrogen bonding), ionic and dipole interactions and hydrophobic interactions (Mayer et al., 1999). Bacteria are transported to the surface by the so-called long-range interactions and upon closer contact, short-range interactions become more important. This initial attachment of bacteria to surfaces is the initial part of adhesion, which makes the molecular or cellular phase of adhesion possible.

\section{Molecular and cellular interactions between bacteria} and surfaces: Phase two

In the second phase of adhesion, molecular-specific reactions between bacterial surface structures and substratum surfaces become predominant. This implies a firmer adhesion of bacteria to a surface by the selectivebridging function of bacterial surface polymeric structures, which include capsules, fimbriae, or pili and slime. In fact, the functional part of these structures should be the adhesins, especially when the substrata are host tissues (Mack, 1999; O'Gara and Humphreys, 2001; Gotz, 2002). $S$. epidermidis has several polysaccharide adhesins that mediate the adhesion of this bacterium to various material surfaces and protein tissues, and the most important are: PS/A; a galactose-rich capsular polysaccharide adhesin composed of $\beta$-1,6-linked $\mathrm{N}$-acetylglucosamines residues with some O-linked substituents of succinate, phosphate and acetate, SAA; a slime-associated antigen composed of N-acetyl-glucosamine, PIA; a polysaccharide composed of $\beta$-1,6-linked $\mathrm{N}$-acetylglucosamines with partly deacetylated residues and AAP; an accumulationassociated protein. PS/A and SAA take part in bacteriamaterial interactions, whereas PIA and AAP interfere in cell-cell interactions. In addition, clumping factors, proteins and teichoic acid may contribute to highly viscous mass. Moreover, bacteria interact with many proteins specifically (for example $S$. aureus with fibronectin) (Fig. 2).

\section{Bacteria-Biomaterial Interactions According to Theoretical Models}

Once microorganisms reach the proximity of a surface, attachment is determined by physical and chemical interactions, which may be attractive or repulsive, depending upon the complex interplay of the chemistries of the bacterial and substratum surfaces, and the aqueous 
phase. To understand the forces that determine adhesion a number of researchers have tried to determine whether bacterial attachment to surfaces is governed by the same physicochemical interactions that determine deposition of nonliving colloidal particles. Three theoretical approaches have been used: the DLVO model, the thermodynamic approach and the extended DLVO theory.

The DLVO theory has been used to describe the net interaction $\left(\mathrm{V}_{\mathrm{TOT}}\right)$ between a cell and a surface as a balance between two additive factors: $\mathrm{V}_{\mathrm{A}}$ resulting from van der Waals interactions (generally attractive) and repulsive interactions $\left(\mathrm{V}_{\mathrm{R}}\right)$ from the overlap between the electrical double layer of the cell and the substratum (Coulomb interactions, generally repulsive due to the negative charge of cells and substratum). Although DLVO could account for experimentally observed low levels of bacterial attachment to negatively charged surfaces, it could not explain the variety of attachment behaviours observed with other types of surfaces or in solutions with appreciable electrolytes. It could be argued that DLVO describes one of several components of the attachment process; that is the probability of an organism overcoming any electrostatic barrier. However, it does not describe the various molecular interactions that would come into play when polymers at the bacterial surface enter into contact with molecular groups on the substratum as well as any conditioning film. Moreover it does not account for structures and molecules on bacterial surfaces that affect cell-surface distance and the exact type of interaction, for the substratum roughness and the fact that correlation between surface charge and adhesion is not straightforward (the effect of charge is more important for adhesion of hydrophilic than hydrophobic cells)

The Thermodynamic theory (Morra and Cassinelli, 1997 ) is the second physicochemical approach that has been used to describe bacterial attachment to surfaces. It takes into account the various types of attractive and repulsive interactions, such as van der Waals, electrostatic or dipole but expresses them collectively in terms of free energy, a thermodynamic term. The approach requires estimation of numerical values of thermodynamic parameters, i.e. surface free energy of the bacterial and substratum surfaces and surface free energy (or surface tension) of the suspending solution, in order to calculate the Gibbs adhesion energy for bacterial adhesion. Adhesion is favored if the free energy per unit surface area is negative as a result of adhesion, which means that spontaneous attachment is accompanied by a decrease in free energy of the system, as predicted by the second law of thermodynamics. From the thermodynamic point of view, there are three different theories, which are more frequently used to account for bacterial adhesion. The Neumann equation, an approach based on polar-dispersion components and the Lewis acid-base theory. Each of these theories attributes a different role to the nature and the molecular details of surfaces and interfaces involved in the adhesive process. They are not generalisations or refinements of the same approach and do not depict different shades of the same subject: rather they are incompatible. The acceptance of one theory leaves no room for the other. I) Neumann's theory accepts that a single contact angle is sufficient to characterise the field of forces arising from the solid surface and that the molecular details do not affect the experimental output. II) The polardispersion approach is successful in predicting the work of adhesion between phases when no specific interfacial interactions exist. However, the assumption that matter interacts through forces arising from permanent dipoles and that this kind of interaction, like the dispersive one, is symmetrical, is in strong contrast with the present view of intermolecular interactions in condensed phases. III) The electron donor-electron acceptor approach is the most advanced theory and the one that uses the presently accepted physical knowledge to account for interfacial interactions. It demonstrates that the permanent dipole contribution to intermolecular forces is negligibly small and that acid-base and in particular the hydrogen bonding is responsible for the interactions. However, the correctness of the quantitative outcome of this theory is still debated.

Generally, the thermodynamic approach assumes that the process is reversible, which however is not the case. Moreover, in the DLVO theory, the interaction energy is distance dependent, whereas in the thermodynamic approach the formation of a new cell-substratum interface at the expense of the substratum-medium interface is calculated, i.e. the strength of the interaction at contact is achieved. If a new cell-substratum interface is not formed, basically the theory is not applicable. Another question is how much of the cell is actually in contact with the substratum. Moreover, the thermodynamic approach is an equilibrium model that does not allow for a kinetic interpretation. Generally, it is very difficult to obtain accurate values for bacterial surface free energies because these surfaces possess complex chemistry and hydration in vivo. Thus, calculations of free energy changes during adhesion may be incorrect. Furthermore, the thermodynamic theory applies to closed systems where no energy is put into the system from outside, bacteria however are living organisms that convert substrate into energy, and adhesion may be driven by energy consuming physiological mechanisms or synthesis of adhesive polymers.

Thus, the application of thermodynamic theory has not been entirely successful in explaining or predicting all the various attachment behaviours observed in bacterial systems. However, this approach helped to explain an increasing common observation: in numerous cases increased hydrophobicity of the solid surfaces or of the bacteria surfaces tended to result in increased numbers of attached cells. For two surfaces to come together, resulting in adhesive molecular interactions, absorbed water must be displaced. If the surface is highly hydrated, such water displacement is energetically unfavourable and may be impossible to overcome by the counteracting attractive interactions.

It is clear from all the above that neither the DLVO nor the thermodynamic approach can fully explain bacterial adhesion. For this reason an extended DLVO theory (Jucker et al., 1998, Hermansson, 1999) has been suggested in which the hydrophobic/hydrophilic 
interactions are included. So, the total adhesion energy can be expressed as:

$$
\Delta \mathrm{G}^{\mathrm{adh}}=\Delta \mathrm{G}^{\mathrm{vdW}}+\Delta \mathrm{G}^{\mathrm{dl}}+\Delta \mathrm{G}^{\mathrm{AB}}
$$

Where, $\Delta \mathrm{G}^{\mathrm{vdW}}$ and $\Delta \mathrm{G}^{\mathrm{dl}}$ are the classical van der Waals (vdW) and double layer ( $\mathrm{dl}$ ) interactions, and $\Delta \mathrm{G}^{\mathrm{AB}}$ relates to acid-base interactions. The later component introduces a component that in principle describes attractive hydrophobic interactions and repulsive hydration effects, which are 10-100 times stronger than the vdW interactions of surfaces in direct contact. The distance dependence, which is important in the calculation of the total adhesion energy, is given from the classical DLVO theory for the $\mathrm{vdW}$ and the double layer interactions and the distance dependence of the surface energy component $\Delta \mathrm{G}^{\mathrm{AB}}$ decays exponentially from its value at close contact. Hence, the acid-base interactions at the first stage of adhesion are not involved, therefore, the measured time dependent strengthening of the cell-substratum interaction is suggested to be due to the cell approaching closer to the surface. The extended DLVO model seems to be a promising way to study bacterial adhesion, however it has not been tested rigorously.

From these considerations it can be concluded that the application of physicochemical theory, although has helped to explain some observations, it has not been entirely successful in predicting all the various attachment behaviors observed in bacterial systems. It may simply manifest the difficulty of applying a physical theory to biological systems. The complexity of bacterial surface polymer composition, as well as the change in polymer composition and synthesis with changing environmental conditions or time can explain much of the variability in experimental observations of bacterial attachment. Clearly, environmental conditions, particularly the types of nutrients and their concentrations can influence the chemical composition of the cell surface polymers. Often, after bacteria have been attached to a surface for hours or days, hydrated amorphous polymers accumulate, together with increasing numbers of attached cells. These polymers form an intercellular matrix in which the cells are embedded and constitute the highly hydrated, slimy matrix that forms a major portion of the bacterial biofilm. As the polymers seem to build up after attachment has occurred, it is possible that attachment to a surface in some ways signals the switching on of polymer synthesis that strengthens cell surface attachment. So far, attachment to surfaces has been shown to induce expression of genes that result in the conversion of cells from single-cell, freeswimming mode to a complex multicellular, surfaceassociated mode of existence (Heilmann et al., 1996; Mack, 1999).

Therefore, cell surface proteins, polysaccharides, conditioning films on surfaces, co-adhesion and biological changes in attaching bacteria may well affect the prerequisites for adhesion to such an extend that prediction of the adhesion process is virtually impossible based only on the physicochemical models. But, a correct translation of the theories that predict adsorption of well-defined colloidal particles, to the field of bacterial adhesion, is very useful in order to form a framework in which biological factors can be added.

\section{Factors Influencing Bacterial Adhesion}

Bacterial adhesion is an extremely complicated process that is affected by many factors including the environmental factors, such as the associated flow conditions, the presence of serum proteins or antibiotics, the bacterial properties and the material surface characteristics. For more details about how these factors influence bacterial adhesion consult the excellent review of An and Friedman (1998). Here additional experimental results are reviewed which also confirm that a better understanding of the relevant environment, the material surface characteristics (physicochemical properties, topography-roughness) and the behaviour of the various bacteria is a prerequisite to the comprehension of the adhesion process in order to strategically act upon it.

\section{Environment}

Certain factors in the general environment, such as temperature, time of exposure, bacterial concentration, the presence of antibiotics and the associated flow conditions affect bacterial adhesion.

Flow conditions are considered dominant factors that strongly influence the number of attached bacteria (Duddridge et al., 1982, Dickinson and Cooper, 1995; Isberg and Barnes, 2002) as well as the biofilm structure and performance (Stoodley et al., 1999; Klapper et al., 2002). It is generally considered that higher shear rates result in higher detachment forces that result in decreasing the number of attached bacteria (Katsikogianni et al., unpublished data)) (Fig. 3), while they make the biofilm denser and thinner (Chang et al., 1991) (Fig. 4).

Once in contact with a material, the bacterium is able to engage in interactions dependent on the surface characteristics of both the bacterium and the material surface. Taking the simplest case of ligand/receptor mediated attachment, the number of bonds that can form will be a function of ligand and receptor densities (Hubble et al., 1996; Mascari et al., 2003). If each bond requires a specific force to break it, the number of bonds between bacterium and surface will determine the shear stress that the attached bacterium will be able to resist. There is an optimum flow rate for bacterial attachment reflecting the balance between rate of delivery and the force acting on attached bacterium (Liu and Tay, 2002). This is also shown in Figure 5 where, in the case of higher number of receptors/cell, S. aureus adhesion to collagen coated coverslips increases between shear rates 50-300 $\mathrm{s}^{-1}$ and then decreases for shear rates higher than $500 \mathrm{~s}^{-1}$ (Mohamed et al., 2000).

On the surface, the number of bonds from the bacterium can increase or decrease. If the bond number drops below a critical value then the bacterium will detach. At flow rates, where shear stress and bond number required to maintain attachment are low, a 10-fold increase in both receptor and ligand concentration have a negligible effect 
on attached bacteria. At higher flow rates, where shear effects lead to higher forces on attached bacteria, the potential to form higher numbers of bonds is of much greater significance (Hubble, 2003).

Moreover, there is evidence that suspended bacteria can respond to shear by altering their growth rate, morphology, bacteria size/density and metabolism (Liu and Tay, 2001, 2002). Higher dehydrogenase activity and lower growth yield are obtained when the shear rate is raised. The reduced growth yield, together with the enhanced catabolic activity, suggests that a dissociation of catabolism from anabolism may occur at high shear rates. Therefore, a biological phenomenon, besides a simple physical effect, may underline the observed relation between the shear rate and the resulting biofilm structure.

Quantitative assessment of the shear stress values favourable to attachment and those required to detach preadsorbed bacteria shows that there is an order of magnitude difference. It has been shown that the shear stress required to generate detachment increases with incubation time up to a maximum value, suggesting that additional interactions are progressively formed after the initial bacterial attachment (Ming et al., 1998).

Moreover, concentrations of electrolytes, such as $\mathrm{KCl}$, $\mathrm{NaCl}$ and $\mathrm{pH}$ value in the culture environment also influence bacterial adhesion (Bunt et al., 1995; Sanderson et al., 1996; McWhirter et al., 2002). Bunt et al. (1993) showed that the $\mathrm{pH}$ and the ionic strength of the suspending buffer influence the cell surface hydrophobicity (CSH). $\mathrm{CSH}$ was found to be significantly lower at higher $\mathrm{pH}(7.4)$ and low ionic strength $(0.5 \mathrm{M})$, while $\mathrm{CSH}$ was greater at $\mathrm{pH} 2.2$ and ionic strength $1 \mathrm{M}$. Greatest adhesion to hydrophobic surfaces was found at $\mathrm{pH}$ between 2.2 and 4 , in the range of the isoelectric point when bacteria are uncharged, and ionic strength $1 \mathrm{M}$. The effect of increased ionic strength is suggested to be due to the suppression of the solvation barrier and the negligible electrostatic interactions (repulsive) (see also Ong et al., 1999). Therefore, ionic strength and $\mathrm{pH}$ influence bacterial adhesion by changing surface characteristics of both the bacteria and the materials (hydrophobicity-charge) and therefore changing interactions in phase 1 .

The presence of antibiotics decreases bacterial adhesion depending on bacterial susceptibility and antibiotic concentration (Schierholz et al., 2000). Kohnen et al. (2003) showed that S. epidermidis adhesion on catheters was reduced when catheters where impregnated with rifampin-sparfoxacin that were released slowly with time from catheter surface.

However, Arciola et al. (2002) showed that adhered S. epidermidis was less susceptible to antibiotic treatment than non-adherent cells. This may be explained by bacterial altered metabolism and a system of bacterial resistance to unfavourable conditions (lower growth rate) after adhesion and slime production, or by selection; under the selective pressure of a drug or due to adhesion to specific surfaces, some antibiotics-resistant mutants could find favourable conditions and preferentially multiply.

\section{INFLUENCE OF FLOW CONDITIONS ON} BACTERIAL ATTACHMENT

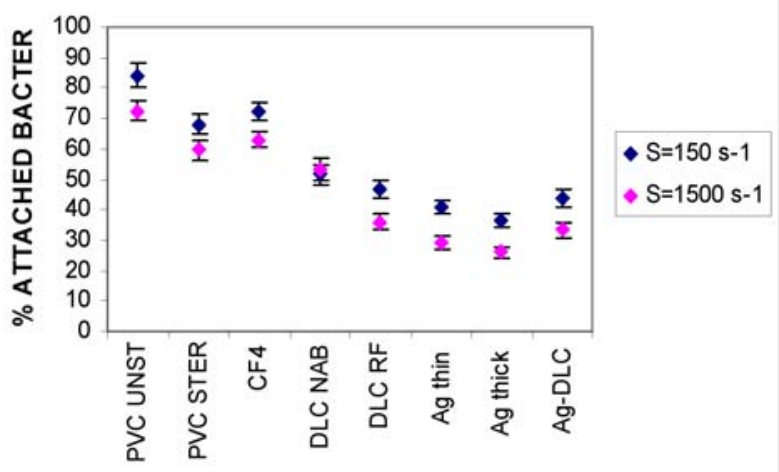

Figure 3. Influence of flow conditions on $S$. epidermidis attachment to plasma modified PVC with CF4, DLC Neutral Atom Beam (NAB) and Radiofrequency (RF), Silver ( $\mathrm{Ag})$ thin and thick and Ag/DLC (Katsikogianni et al., unpublished data).

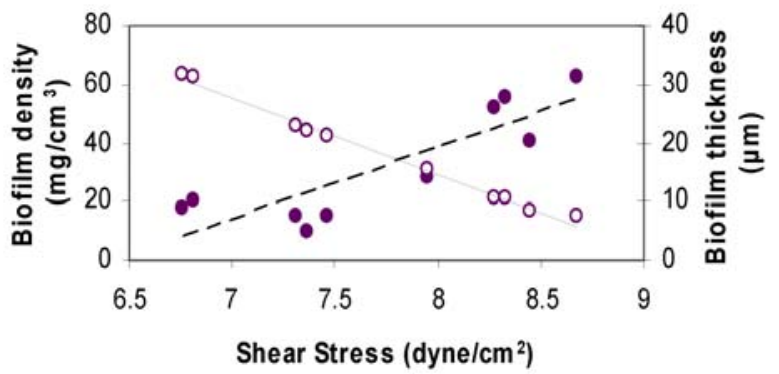

Figure 4. Influence of flow conditions on bacterial biofilm density (filled circles) and biofilm thickness (open circles) (Chang et al., 1991).

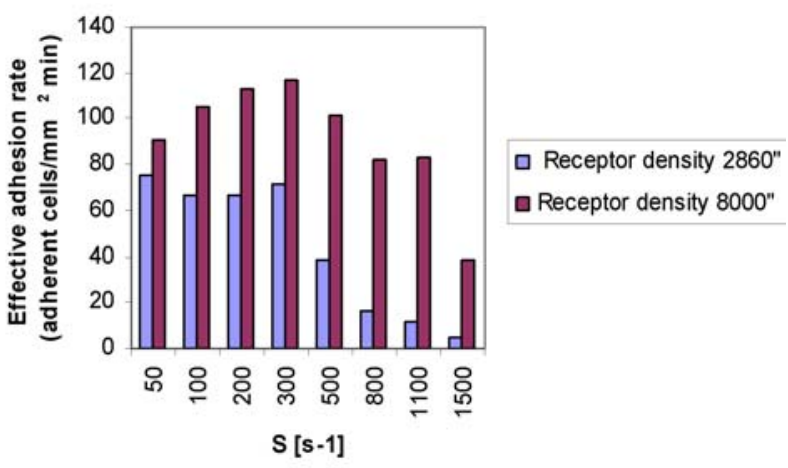

Figure 5. Influence of flow conditions on $S$. aureus (with number of receptors/cell either 2860 or 8000 ) adhesion to collagen coated coverslips $\left(9.8 \mu \mathrm{g} / \mathrm{cm}^{2}\right)$ (Mohamed et al., 2000). 


\section{Material surface characteristics}

The factors influencing bacteria adherence to a biomaterial surface include chemical composition of the material (Cordero et al., 1996; Kiremitci-Gumustederelioglou and Pesmen, 1996; Gottenbos et al., 2000; Tegoulia and Cooper, 2002; Buczynski et al., 2003; Henriques et al., 2004; Speranza et al., 2004), surface charge (Gottenbos et al., 1999), hydrophobicity (Balazs et al., 2003) and simply surface roughness or physical configuration (Scheuerman et al., 1998).

\section{Surface chemical composition}

Surface chemistry influences bacterial adhesion and proliferation (Fig. 1). Materials with different functional groups change bacterial adhesion in a manner depending on material hydrophobicity and charge. Tegoulia and Cooper (2002) showed that S. aureus adhesion on selfassembled monolayers (SAMs) terminated with methyl, hydrohylic, carboxylic acid and tri (ethylene oxide) was lowest on ethylene oxide-bearing surfaces $\left(\mathrm{EG}_{3}\right)$ followed by the hydroxyl surfaces and higher on carboxylic- and methyl-terminated SAMs (Fig. 6). The attachment of $S$. aureus to the surfaces other than $\mathrm{EG}_{3}$ corresponds well with the thermodynamic theory (Contact angles: $\mathrm{CH}_{3}: 100$, $\mathrm{CH}_{2} \mathrm{OH}: 12$, COOH: 25, $\mathrm{EG}_{3}: 34$ ). This may be explained by the fact that $\mathrm{EG}_{3}$ provides a template for water nucleation and a stable interfacial water layer so that it prevents direct contact between bacteria and surface. KiremitciGumustederelioglou and Pesmen (1996) showed that bacterial adhesion was reduced on the negatively charged PMMA/AA (acrylic acid), while it was increased on the positively charged PMMA/DMAEMA (dimethylamino ethyl methacrylate) in a manner depending on the comonomer content (Fig. 6).

If the surface chemistry is changed or modified, such as with silver (Woodyard et al., 1996; Silver, 2003; Katsikogianni et al., unpublished data), DLC (Hauert, 2003) and plasma coatings (Francois et al., 1996; Davenas et al., 2002; Balazs et al., 2003; Whitehead et al., 2004), bacterial adhesion to these surfaces is hindered. Balazs et al. (2003) showed that oxygen glow discharged PVC decreased bacterial adhesion due to significant alteration in the hydrophilicity of the native PVC after oxygen glow discharge treatment from $80^{\circ}$ to $20^{\circ}$ (Fig. 7). James and Jayakrishnan (2003) showed that surface thiocyanation of PVC decreased bacterial adhesion (S. epidermidis, $S$. aureus) due to alteration in the hydrophilicity of the native PVC after thiocyanation from $72^{\circ}$ to $50^{\circ}$. In our recent unpublished data we showed that plasma modified PVC with, $\mathrm{CF}_{4}$, DLC (Atom Beam: AT and RF), Silver (Ag) (thin, thick), Ag/DLC changed S. epidermidis adhesion in comparison to native PVC. $\mathrm{CF}_{4}$ increased bacterial adhesion due to its hydrophobicity while $\mathrm{Ag}$ thick followed by Ag thin decreased bacterial adhesion due to its antibacterial effect. Ag/DLC decreased adhesion but to a lower extend maybe due to its surface roughness. DLC (RF) decreased bacterial adhesion but to a lower extend than DLC (Neutral Atom Beam) maybe due to its surface roughness (Fig. 7).

Modifying the surface with peptide coatings (Park et al., 1998; Shi et al., 2000; Harris et al., 2004) and

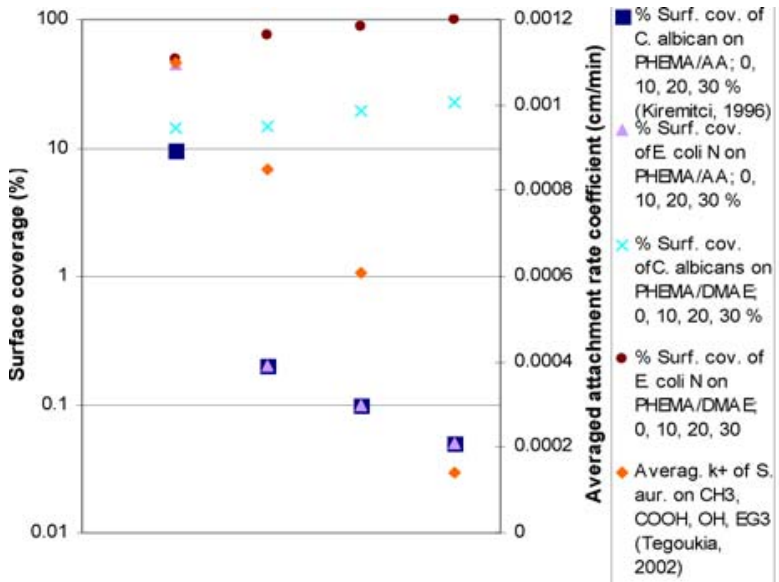

Figure 6. Microbial adhesion (C. albicans, E. coli) as a function of AA and DMAE content (KiremitciGumustederelioglou and Pesmen, 1996) and averaged $S$. aureus attachment rate constants $\left(S=50-200 \mathrm{~s}^{-1}\right)$ for $\mathrm{CH}_{3}, \mathrm{OH}, \mathrm{COOH}, \mathrm{EG}_{3} \mathrm{SAMs}$ (Tegoulia and Cooper, 2002) (points corresponding to different chemistry from left to right).

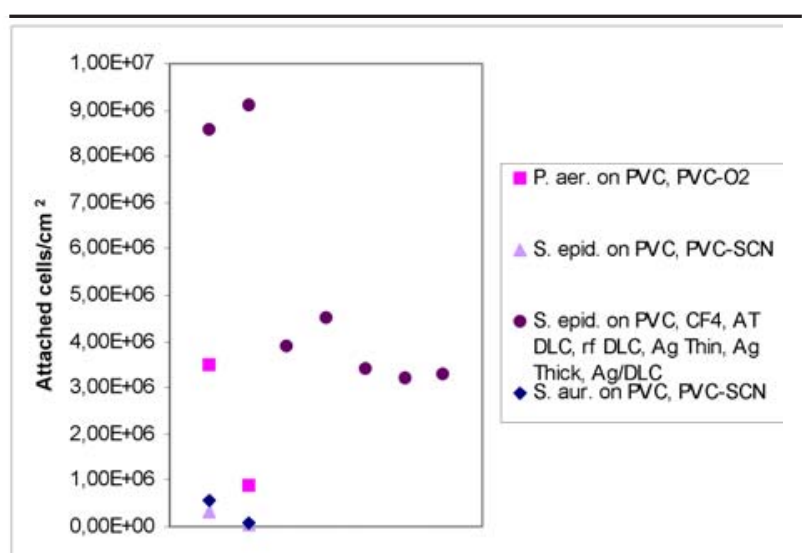

Figure 7. Pseudomonas aeruginosa adhesion on PVC, PVC-O (static, 2 h incubation, Balazs et al., 2003), S. epidermidis and $S$. aureus adhesion on PVC, PVC-SCN $\left(10^{6} \mathrm{CFU} / \mathrm{ml}\right.$ in TSB, agitation 80 times/min, $24 \mathrm{~h}$ incubation, James and Jayakrishnan, 2003), S. epidermidis adhesion on plasma modified PVC with $\mathrm{CF}_{4}$, DLC (AT and RF), Silver (Ag) (thin, thick), Ag/ DLC $\left(3 * 10^{8} \mathrm{CFU} / \mathrm{ml}\right.$ in PBS, 2:30 h, flow, $50 \mathrm{~s}^{-1}$, Katsikogianni et al., unpublished data) (points corresponding to different chemistry from left to right).

nonsteroidal anti-inflammatory drug coating (Paulsson et al., 1994; Flemming et al., 2000; Vacheethasanee and Marchant, 2000; James and Jayakrishnan, 2003; Baveja et al., 2004) discourages bacterial adhesion.

Park et al. (1998) showed that poly(ethylene glycol) PEG1k (M.W. 1000), PEG1K-OH, and especially longer poly(ethylene glycol) chains PEG-3.4k-OH (M. W. 3350) and PEG-3.4k-Heparin modified PU decreased bacterial adhesion in comparison to PU due to their hydrophilicity (Contact angles: PU: 93, PU-PEG1K-OH: 44) Sulfonated (data not shown) and heparin terminated PEG showed the highest reduction in bacterial adhesion maybe due to the fact that these terminants adsorb less amount of proteins 
Table 3. Contact angles of three polymeric surfaces before and after coating with mucin (Shi et al., 2000)

\begin{tabular}{l|l|l}
\hline Materials & Before coating & $\begin{array}{l}\text { After } \\
\text { coating }\end{array}$ \\
\hline Silicone & $90.8+-0.5$ & $50.8+-3.2$ \\
\hline Polystyrene & $115+-2.9$ & $8.5+-0.41$ \\
\hline PMMA & $75+-1.2$ & $<5$ \\
\hline
\end{tabular}

(Fig. 8, see also Fig. 14). Shi et al. (2000) showed that mucin coating on PMMA, PS and silicone decreased bacterial adhesion due to their increased hydrophilicity in comparison to uncoated materials (Table 3, Fig. 8).

\section{Surface roughness}

It has been found that the irregularities of polymeric surfaces promote bacterial adhesion and biofilm deposition whereas the ultrasmooth surface does not favour bacterial adhesion and biofilm deposition (Scheuerman et al., 1998). This may happen since a rough surface has a greater surface area and the depressions in the roughened surfaces provide more favourable sites for colonization.

A small increase in surface roughness of PMMA(Table 4) treated with silicone carbide paper grade P1200 had a significant increase in bacterial adhesion, while, larger roughness increases produced by silicone carbide paper grades P400 and P120, had no significant effect in bacterial adhesion compared to the smooth surface (Taylor et al., 1998) (Fig. 9).

Boyd et al., 2002 showed that an increase in surface roughness on stainless steel, from $0.04 \mu \mathrm{m}$ (average peak to valley distance, AFM measurements) for polished stainless steel to $0.30 \mu \mathrm{m}$ for abraded, increased bacterial adhesion strength more than a larger increase in surface roughness from $0.04 \mu \mathrm{m}$ to $0.96 \mu \mathrm{m}$ for unpolished stainless steel. This means that under the same tip- surface force during scanning with an AFM tip (see also AFM technique description) more cells remained on abraded stainless steel than on unpolished and especially polished stainless steel (Fig. 10).

The cause of this non-linear dependence of bacterial adhesion on surface roughness is a question for further studies such as broader range of surface roughness, surface area measurement or analysis of surface configuration.

\section{Surface configuration}

It has been found that implant site infection rates are different between porous and dense materials with porous materials having a much higher rate. This implies bacteria adhere and colonize the porous surface preferentially. Moreover bacteria adhere more to grooved and braided materials compared to flat ones, probably partially due to increased surface area (Scheuerman et al., 1998; Bos et al., 2000; Medilanski et al., 2002). However, bacteria preferentially adhere to irregularities that conform to their size since this maximizes bacteria-surface area (our data) (Fig. 12). Grooves or scratches that are on order of bacterial size increase the contact area and hence the binding

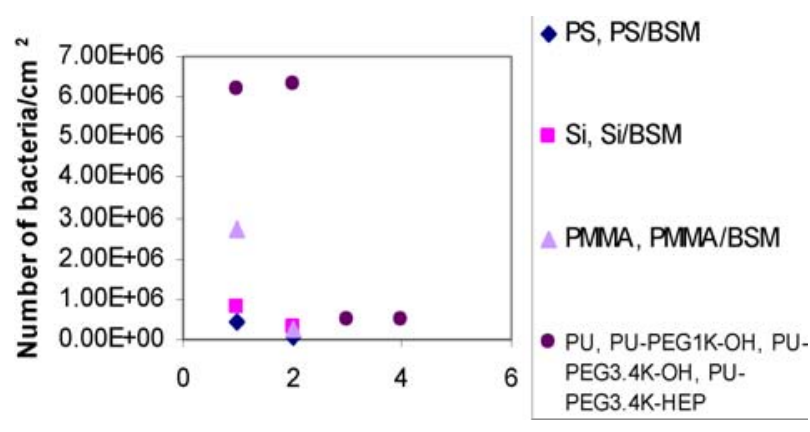

Figure 8. S. epidermidis adhesion on PS/BSM, $\mathrm{Si} /$ BSM, PMMA/BSM $\left(5^{*} 10^{7} \mathrm{CFU} / \mathrm{ml}, 80 \mathrm{rpm}, 2 \mathrm{~h}\right.$ incubation, Shi et al., 2000) and $S$. epidermidis adhesion on PU, PU-PEG1k-OH, PU-PEG3.4k-OH, PUPEG3.4k-HEP $\left(1 * 10^{7} \mathrm{CFU} / \mathrm{ml}\right.$, swirling, 24 h, Park et al., 1998).

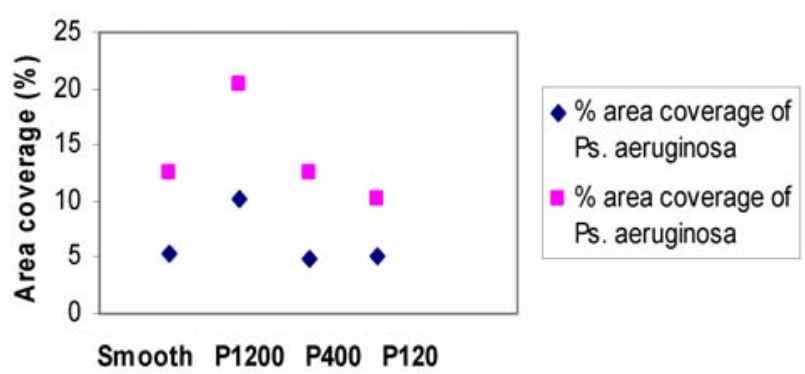

Figure 9. The adhesion of Pseudomonas aeruginosa and S. epidermidis, following $1 \mathrm{~h}$ incubation to smooth, P1200, P400 and P120 PMMA. (Taylor et al., 1998).

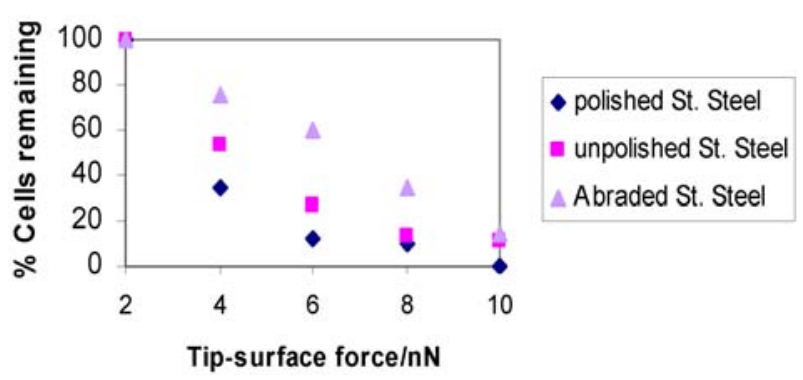

Figure 10. Effect of surface roughness on S. aureus adhesion strength. Increasing the shear force causes a greater portion of the attached bacteria to be displaced especially for polished and unpolished Stainless steel (Boyd et al., 2002).

Table 4. The surface topography of smooth and roughened PMMA, measured by laser profilometry.

\begin{tabular}{lrrr}
\hline $\begin{array}{l}\text { Type of } \\
\text { roughness }\end{array}$ & $\mathrm{Ra}(\mu \mathrm{m})$ & $\mathrm{Rz}(\mu \mathrm{m})$ & $\mathrm{Rlo}(\mu \mathrm{m})$ \\
\hline Smooth & 0,04 & 0,94 & 4,01 \\
P1200 & 1,24 & 10,1 & 5,34 \\
P400 & 1,86 & 14,5 & 5,38 \\
P1200 & 3,66 & 25,3 & 5,34 \\
\hline
\end{tabular}

Ra: arithmetic mean of the departures of the roughness profile from the profile centre-line. Rz: average distance between the five highest peaks and the five lowest valleys. Plo: distance of the peaks and valleys that make up the tracing length (Taylor et al., 1998). 
potential, whereas grooves that are much larger-wider than the bacterial size approach the binding potential of a flat surface. Grooves or scratches too small, for the bacterium to fit them, reduce the contact area of the bacterium and hence binding (Edwards et al., 2001) (Fig. 11).

\section{Bacterial characteristics}

For a given material surface, different bacterial species and strains adhere differently since different species and strains have different physicochemical characteristics.

\section{Bacterial hydrophobicity}

Generally, bacteria with hydrophobic properties prefer hydrophobic material surfaces; the ones with hydrophilic characteristics prefer hydrophilic surfaces. Vacheethasanee et al. (1998) showed that more hydrophobic S. epidermidis adhered to a greater extent than the less hydrophobic $S$. epidermidis to $\mathrm{PE}$ for shear stresses between $0-8 \mathrm{dyn} / \mathrm{cm}^{2}$ in PBS, whereas the differences in adhesion for high and low hydrophobic bacteria decreased with increasing shear stresses. The correlation between bacterial surface hydrophobicity and adhesion disappeared at shear stress higher than $15 \mathrm{dyn} / \mathrm{cm}^{2}$. In PPP, positive correlation between bacterial surface hydrophobicity and adhesion was at $0 \mathrm{dyn} / \mathrm{cm}^{2}$ (Fig. 13). However it has been shown that material surface hydrophobicity plays a more important role in bacterial adhesion than bacterial surface hydrophobicity even for shear stresses up to $65 \mathrm{dyn} / \mathrm{cm}^{2}$.

\section{Bacterial surface charge}

Most particles acquire a surface electric charge in aqueous suspension due to the ionization of their surface groups. Bacteria in aqueous suspension are almost always negatively charged. The surface charge of bacteria varies according to bacterial species and is influenced by the growth medium, the $\mathrm{pH}$ and the ionic strength of the suspending buffer, bacterial age, and bacterial surface structure.

However, the relative contribution of bacterial surface charge to bacterial adhesion has not been clearly understood.

\section{Serum or tissue proteins}

Serum or tissue proteins, such as albumin, fibronectin, fibrinogen, laminin, denaturated collagen and others, promote or inhibit bacterial adhesion by either binding to substrata surfaces, binding to the bacterial surface or by being present in the liquid medium during the adhesion period. Most of the bindings between bacteria and proteins are specific ligand-receptor interactions (Miorner et al., 1980).

Fibronectin. Fibronectin (Fn), clearly promotes $S$. aureus adhesion to the substratum surface (Vaudaux et al., 1984; Herrmann et al., 1988). The binding of Fn to a strain of $S$. aureus is specific, time-dependent and irreversible. Therefore, in the presence of Fn, the adherence of $S$. aureus to foreign surfaces is significantly increased.

However, there are controversies regarding the Fn effect on S.epidermidis adhesion to material surfaces (Herrmann et al., 1988).

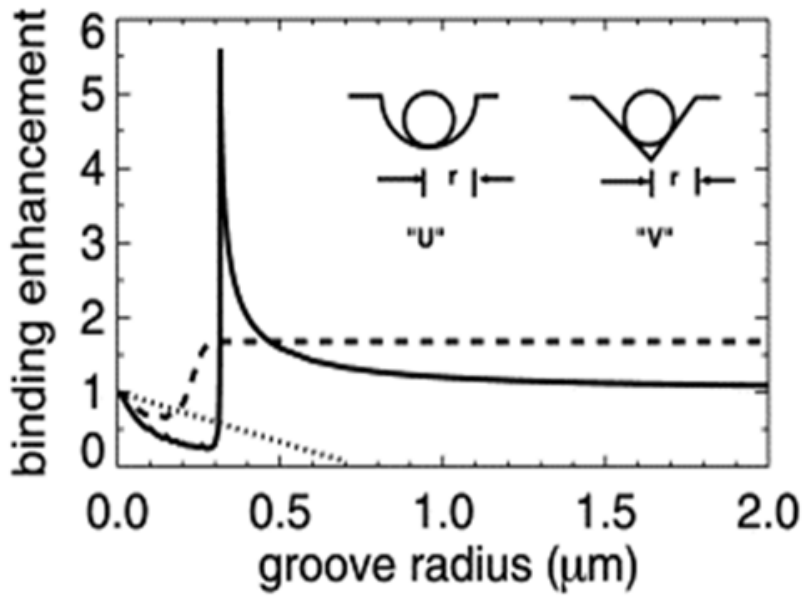

Figure 11. The binding enhancement over a flat surface as a function of groove radius $r$ for " $U$ "-shaped and "V" shaped grooves (solid and dashed lines, respectively). The bacterial radius is $0.32 \mu \mathrm{m}$, which coincides with the discontinuous increase in binding strength at the radius for " $U$ "-shaped grooves. No such discontinuity is seen with " $\mathrm{V}$ "-shaped grooves, though both exhibit a reduced binding below the bacterial radius, and enhanced binding above the bacterial radius. Also shown is the binding strength for bacteria aligned perpendicular to the groove (dotted), which applies to either groove profile. Bacteria will preferentially align perpendicular to the groove if the groove is much less than the bacterial radius. (Edwards et al., 2001).

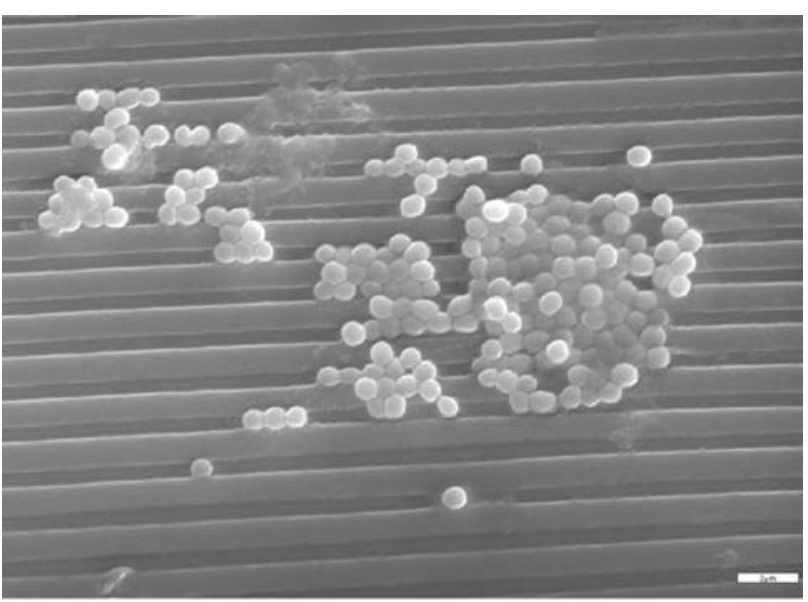

Figure 12. S. epidermidis $\left(3 * 10^{8} \mathrm{CFU} / \mathrm{ml}\right)$ adhesion on PCL grooved, $10 \mathrm{Mrad}$ under static conditions for $300 \mathrm{~min}$. (Katsikogianni et al., unpublished data).

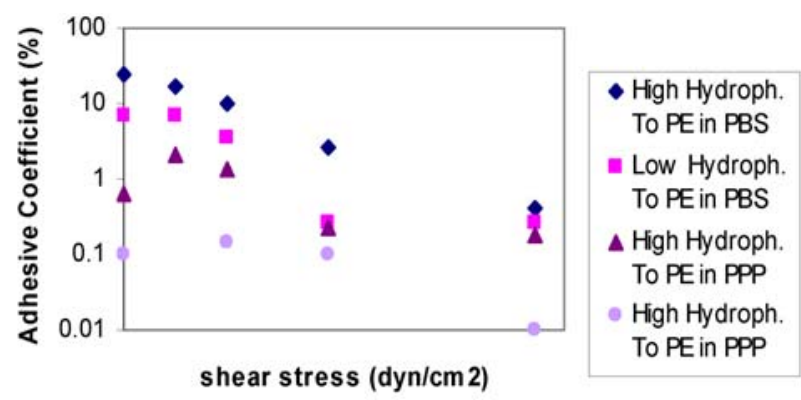

Figure 13. High and low hydrophobic S. epidermidis adhesion to PE in PBS and 1\% PPP under the influence of flow conditions (Vacheethasanee et al., 1998). 
Albumin. Albumin adsorbed on material surfaces has shown obvious inhibitory effects on bacterial adhesion to polymer, ceramic and metal surfaces. Dickinson et al. (1997) showed that albumin inhibited S. aureus adhesion to base polyurethane (PEU-B), positively charged aminated polyurethane (PEU-N) and to negatively charged sulfonated polyurethane (PEU-S) (Fig. 14). Moreover, they showed that albumin inhibited bacterial adhesion in a manner depending on shear rate; increasing shear rate decreases $S$. aureus adhesion to albumin coated PEU-N (Fig. 15).

Albumin may inhibit the adhesion by means of binding to the bacterial cells or by changing the substratum surface to more hydrophylic (Fletcher and Marshall, 1982.)

Fibrinogen. Most studies showed that adsorbed fibrinogen promotes adherence of bacteria, especially staphylococci to biomaterials (Dickinson et al., 1995; Dickinson et al., 1997; Tegoulia and Cooper, 2002). Moreover, pretreatment of bacteria or both bacteria and material surface with fibrinogen enhances bacterial adherence in a manner non-depending on shear rates up to $200 \mathrm{~s}^{-1}$ (Figs. 14 and 15) suggesting the presence of ligands for fibrinogen on the staphylococcal cell surface. Recently, the mediating role of fibrinogen, fibrin and platelet integrin on $S$. aureus adhesion to surface-bound platelets was shown (Fallgren et al., 2002).

Thrombin. Thrombin increases significantly bacterial adhesion since it polymerises fibrinogen in PPP to fibrin. Fibrin strands surround and link the platelet aggregate to stabilize the thrombus, which also promotes bacterial adhesion (Fig. 14) (Baumgartner et al., 1998).

Poor Platelet Plasma-Serum. The adhesion of various CoNS onto plasma coated materials is much lower than onto the untreated control surfaces (Fig. 13: Vacheethasanee et al., 1998; Fig. 14: Dickinson et al., 1997). This effect of pure platelet plasma and serum is mainly due to albumin while IgG and Fn are less effective and due to Vroman effect in which fibrinogen can be displaced by other proteins present in plasma, such as high molecular weight. However PPP with thrombin increases bacterial adhesion (Figure 14)

Platelets. Baumgartner and Cooper (1997) showed that platelets increased $S$. aureus adhesion in comparison to HSA and especially in combination with PPP and thrombin (Fig. 14). Adherent-activated platelets undergo extensive changes including activation of surface receptors and release of proteins stored in granules such as serotonine and von Willebrand factor (vWf). Activated platelets bind several soluble plasma proteins: vWF, fibrinogen, thrombospondin, fibronectin, therefore, they promote bacterial adhesion.

\section{Techniques Used in Evaluating Bacteria-Material Interactions}

In this part a number of different techniques that have been used to evaluate, in a more quantitative manner, cellmaterial interactions are outlined (Missirlis and Spiliotis, 2002). The common element in all of them is that they measure the probability, the force or the energy of attachment/detachment of either many or single bacterial

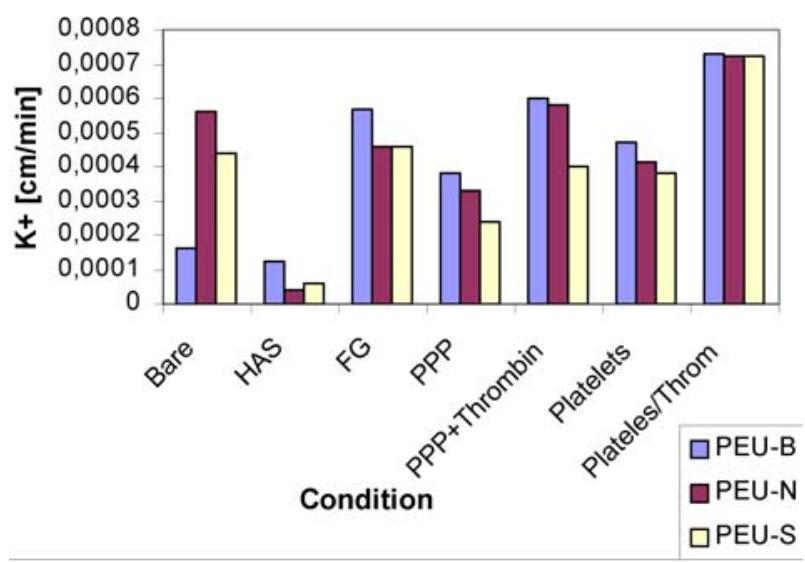

Figure 14. Shear-averaged attachment rate constants (over the range of $35 \mathrm{~s}^{-1}$ to $200 \mathrm{~s}^{-1}$ ) of $S$. aureus adhesion to bare ( $2 \mathrm{~h}$ in buffer alone) PEU-B, PEU-N, PEU$\mathrm{S}$ and to coated ones with: HSA ( $1 \mathrm{~h}$ in buffer, $1 \mathrm{~h}$ in 0,5\% human albumin); FG: $1 \mathrm{~h}$ in $20 \mu \mathrm{g} / \mathrm{ml}$ fibrinogen (see below) then in 0,5\% albumin; PPP: $20 \mathrm{~min}$ in 3\% platelet poor plasma; PPP+Thrombin: $20 \mathrm{~min}$ in 3\% PPP then $20 \mathrm{~min}$ in $5 \mathrm{U} / \mathrm{ml}$ thrombin; platelets: $1 \mathrm{~h}$ in $10^{7}$ platelets $/ \mathrm{ml}$ then $1 \mathrm{~h}$ in $1 \% \mathrm{HSA}$, platelets+Thrombin: $1 \mathrm{~h}$ in $10^{7}$ platelets $/ \mathrm{ml}$, then 20 min in $5 \mathrm{U} / \mathrm{ml}$ thrombin (see below) (Dickinson et al., 1997; Baumgartner and Cooper, 1997)
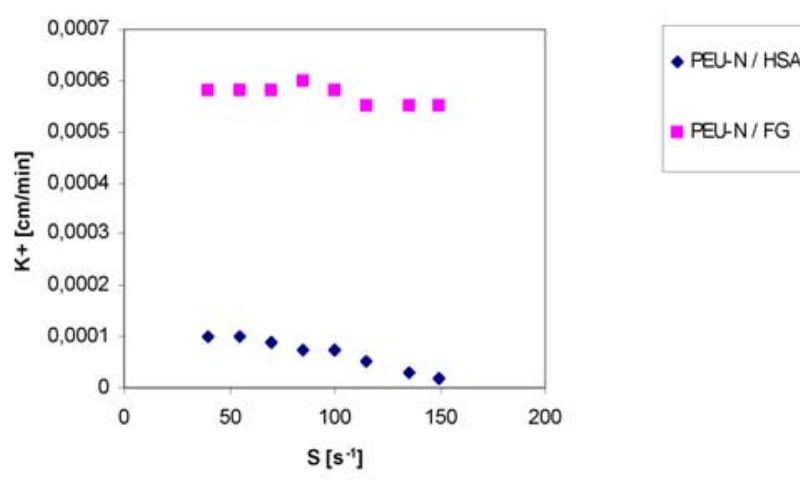

Figure 15. Influence of shear rates attachment rate constants of $S$. aureus adhesion on PEU-N coated with HSA or with FG and then albumin. (Dickinson et al., 1997).

cell. It should be emphasised, however, that these, in vitro, simplified measurements might be misleading, as the whole system is complex and dynamic. In vivo, the substrate is usually under a dynamic mechanical stress state, the surface may change composition with time and biological fluid flow may interact with the surface. Moreover, an incoming bacterium may just attach to the surface (reversibly) or adhere firmly (irreversibly) or release a number of substances and/or present a number of adhesive receptors whose specificity, activity and numbers may be a function of time. But, in any case, further investigations are still needed to advance our understanding of the mechanisms of bacterial adhesion and prosthetic infection and the below techniques are the most proper for this purpose. 


\section{Static assays}

There are simple, inexpensive, straightforward systems to study bacterial adhesion on different surfaces. The principle is as follows: a previously prepared surface is overlaid with a suspension of cells for a determined period of time. Afterwards, the non-adherent cells are removed by rinsing or centrifugation and the remaining (adhered) cells on the surface are counted. When centrifugation is used to detach the non-adherent or weakly adherent bacteria an overall estimation of the strength of adhesion may be calculated. The remaining (adhered) bacteria and biofilm can be examined by a number of methods, which are the following (An and Friedman; 1997),

1. Microscopy for Counting and Morphological Observation of Adherent Bacteria

Light microscopy

Image-analysed epifluorescence microscopy

(Imunofluorescence, Fluorescence In Situ

Hybridisation: Krimer et al., 1999; Moter et al., 2000) Scanning Electron Microscopy (SEM)

Scanning Confocal Laser Microscopy

Atomic Force Microscopy

2. Viable Bacterial Counting Methods

- CFU plate counting

Radiolabelling

CTC staining

3. Other Direct and Indirect Methods

- Spectophotometry

Coulter Counter

- Biochemical Markers (ATP)

4. Methods of Evaluating Slime or Biofilm

- Recognising Biofilm

- Thickness, Density Measurements (SEM, Confocal)

- Morphological Observations

- Measurement of Biofilm Content

The main disadvantage of the static assay is that it is a qualitative, or semi-quantitative at best, test, and that it registers the overall number of bacteria with varying degree of attachment that have been detached.

\section{Parallel-plate flow chambers}

The parallel-plate flow configuration is very common as it is simple to construct and the general flow within the chamber can be mathematically analysed rather easily. In the most commonly used variation a pump provides a steady-state flow, the fluid enters from one side and leaves from the opposite side in a rectangular chamber (Bruinsma et al., 2001; Bakker et al., 2003). The upper plate is usually a glass coverslip while the bottom is the prepared surface (transparent or otherwise) on which the cells have been left to settle for a predetermined time. The fluid movement creates a shear stress at the wall, which is calculated from equation (2).

$$
\tau_{\mathrm{w}}=\Delta \mathrm{Ph} / 2 \mathrm{~L}
$$

where $\Delta \mathrm{P}$ is the pressure drop (outlet-inlet pressure), $\Delta \mathrm{P}=\left(12 \mathrm{~L} / \mathrm{h}^{3} \mathrm{~W}\right) \mu \mathrm{Q}$, where $\mathrm{h}$ is the height, $\mathrm{L}$ is the length and $\mathrm{W}$ is the width of the chamber, $\mu$ is the fluid viscosity

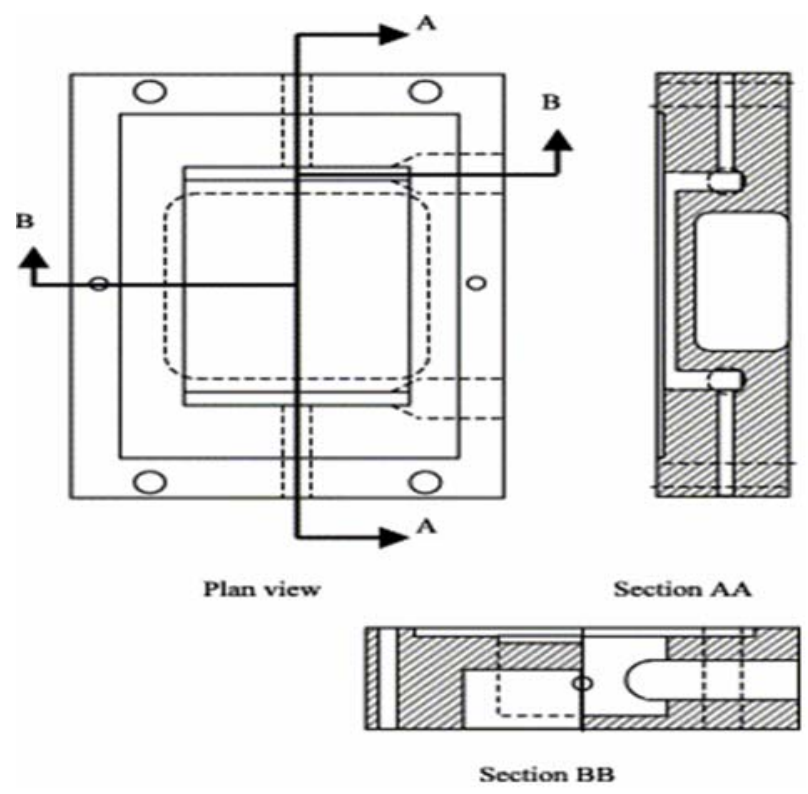

Figure 16. Diagram of a parallel-plate flow chamber (Missirlis and Spiliotis, 2002).
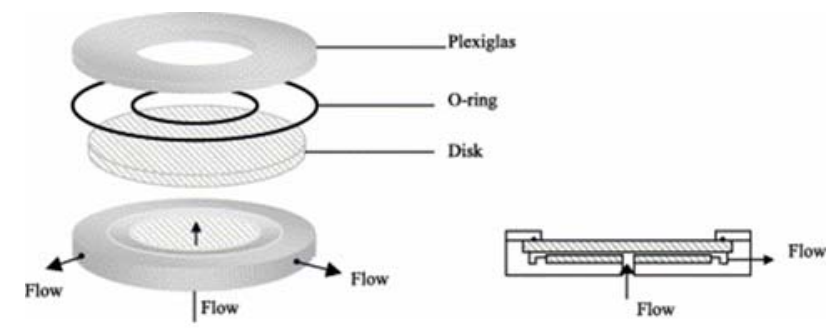

Figure 17. Diagram of a radial flow chamber (Dickinson et al. 1997).
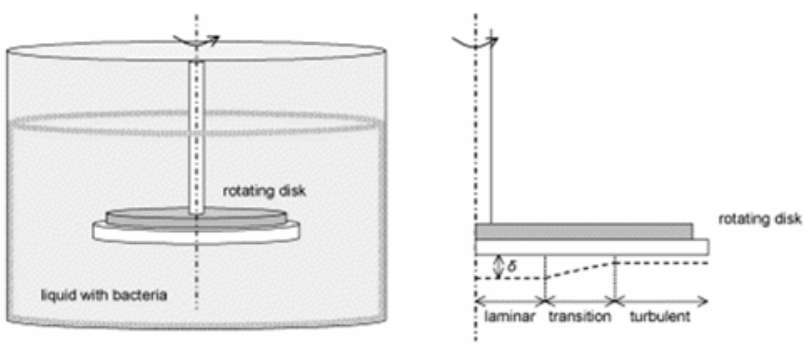

Figure 18. Diagram of Rotating Disc (DeJong et al., 2002)

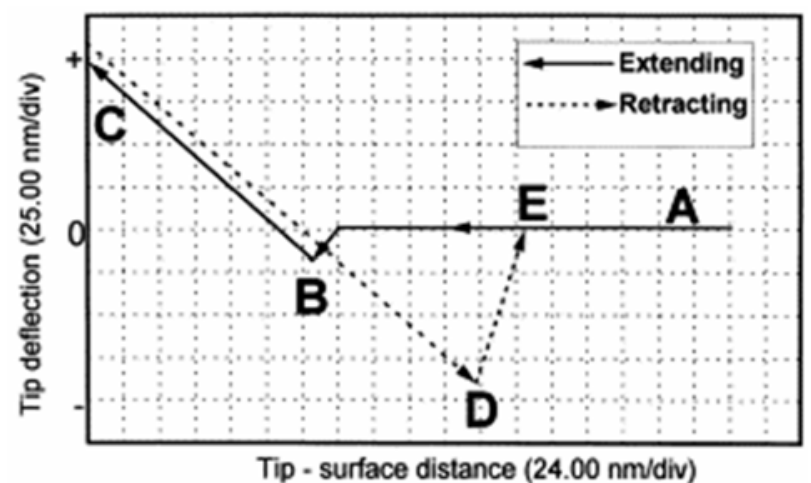

Figure 19. Force-distance curve 
and $\mathrm{Q}$ is the volumetric flow rate.

The assumption is that the wall shear is approximately equal to the shear that is exerted on the cells, as the size of bacteria is many orders of magnitude less than the chamber height. A typical schematic of such a chamber is shown in Figure 16.

Similar chambers can be found in many publications. The bottom plate of the parallel plate flow chamber can be observed with a CCD-MXR camera mounted on a phase-contrast microscope. The camera can be coupled to an image analyzer. In each experiment, images are taken of three different locations on the surface prior to challenging the adhering bacteria with the high detachment force and after. This force can be exerted by a passing liquid-air interface or by increasing the shear stress (by increasing Q). A liquid-air interface can be created by introducing an air-bubble in the flow chamber that completely span the width of the chamber. Apart from the camera and the phase-contrast microscope, all the other techniques, which mentioned in the static assays, can be used in order to evaluate bacterial adhesion and detachment.

\section{Radial flow chamber}

Another configuration of chambers is that of Radial Flow Chamber (RFC), (Fig. 17). Briefly, the RFC (we also used in our recent experimental work) consists of two flat disks separated by a thin gap $(200 \mu \mathrm{m})$. The fluid dynamics in the RFC has been well characterized elsewhere (Dickinson and Cooper, 1995). For a given volumetric flow rate (Q), the shear rate on the collector surface (S) is inversely proportional to the radial position from the inlet port (r) and is calculated from the gap width (h) using the relation:

$$
\mathrm{S}=3 \mathrm{Q} / \pi \mathrm{rh}^{2}
$$

Such a flow pattern provides a gradient of shear stresses becoming progressively lower at the outer edges of the disks.

Apart from the steady-state flows, other dynamic flow patterns can be imposed, including pulsatile or reversible steady-state flows. For example angular acceleration of a parallel disk impart high shear stress transients to attached bacteria.

\section{Rotating disc}

Other fluid shear systems have been used as well, such as the rotating disc in liquid (Fig. 18), whereby in the hydrodynamic boundary layer, the radial and axial velocity are larger than zero (DeJong et al., 2002). Outside the hydrodynamic boundary layer, there is only axial flow. Along the surface, three regions can be distinguished: a laminar flow region, a transient region and a turbulent flow region.

For the rotating disk used in the laminar flow region, the shear stress varies between 3.5 and $13.1 \mathrm{~N} \mathrm{~m}^{-2}$ and in the turbulent region the shear stress is between 694 and $1124 \mathrm{~N} \mathrm{~m}^{-2}$.

In all these systems the major concern is that the measured adhesion strength of bacteria to substrates is

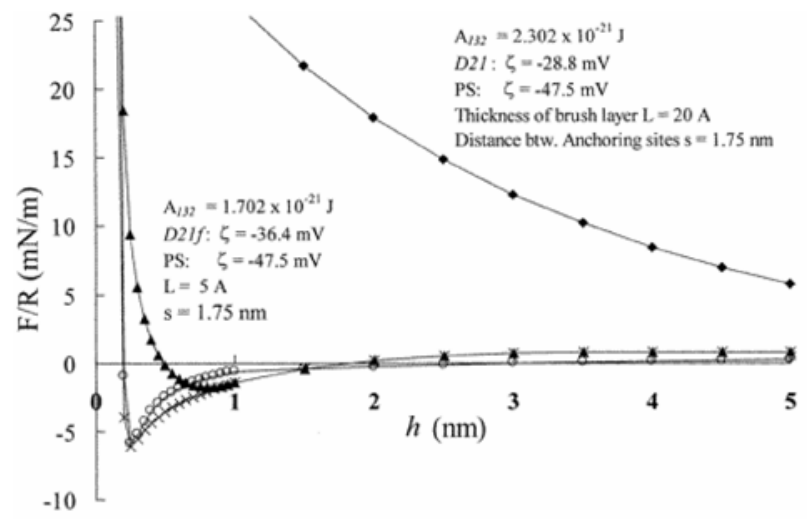

Figure 20. Theoretical force-distance curves incorporating steric effects into an augmented DLVO model for E. coli D21f2 and D21 interacting with polystyrene. Legend: ×, D21f2, extended-DLVO model; Triangular, D21f2, extended-DLVO model + steric effects; Rectangular, D21, extended-DLVO model; Rectangular , D21, extended-DLVO model + steric effects.

global (populations of bacteria) and probabilistic from a material assessment or even from a clinical point of view. In this respect they have certain merits. If, on the other hand, a more focused investigation on the mechanisms, both thermodynamic and kinetic, of the bacteria-materials interactions is sought, techniques involving the manipulation of single bacterium are more pertinent. In the following, such techniques will be briefly presented.

\section{Atomic force microscopy}

The Atomic Force Microscope (AFM) has become a powerful tool in biology and microbiology (Zlatanova et al., 2000; Bolshakova et al., 2001; Dufrene, 2001; Dufrene, 2002). Apart from the fact that AFM has proved useful in imaging the morphology of individual microbial cells and bacterial biofilm on solid surfaces, both in dried and hydrated states (Robichon et al., 1999), it is being used increasingly for mapping interaction forces at microbial surfaces (Bowen et al., 1998; Willing et al., 2000; Beech et al., 2002; Boyd et al., 2002; Alfonso et al., 2003; Dufrene, 2003;), such as van der Waals and electrostatic forces, solvation forces and steric/bridging forces, and for probing the local mechanical properties of bacteria surface layers and of single bacterium.

Therefore, a major advantage of the AFM over other microscopical techniques is that it can simultaneously provide information on local surface properties and interaction forces. Force measurements are made by recording the deflection of the cantilever while the sample is moved up and down. After proper corrections, a so-called "force-distance curve" (Fig. 19) is obtained in which the force experienced by the probe is plotted as a function of the probe-sample separation distance. A force-distance curve records the variations of interaction forces as the bacteria-sample approaches the AFM tip, makes contact and then retrieves from the tip. Such a force-distance curve provides valuable information on the tip-bacteria interaction forces over the various sections of a bacterial cell surface and at various interfacial regions after the 
preliminary formation of biofilm. From the slope of the repulsive section of a force-distance curve, the bacterium surface elasticity can be measured. Therefore, adhesion forces on single bacterium cell surface, on cell-cell interface and on the periphery of the cell-substratum contact surface can be measured as well as elasticity. This may lead to a better understanding of the biofilm formation mechanism.

Interaction Forces. To gain insight into the forces involved in microbial adhesion, several experimental approaches using AFM have been developed. Fang et al. (2000) measured the interactions between standard silicon nitride and confluent layers of sulfate-reducing bacteria (SRB) attached to mica in air (Table 5)

Razatos et al. (1998) measured as well the interactions between standard silicone nitride probes and confluent layers of E. coli strains immobilized on solid substrata (glass) using polyethyleimine and glutaraldehyde, in liquid (Table 6). The strains that used were D21f2: that synthesizes progressively truncated core polysaccharide chains (more hydrophobic) and D21: that synthesizes complete polysaccharide strains (more hydrophilic). However, the possibility of an artifact caused by the chemical fixation procedure cannot be completely ruled out.

Alternatively, microbial cells were immobilized on AFM probes and forces were measured between the modified probes and the solid substrata (Lower et al., 2000). Ong et al. (1999) measured forces between E. coli(D21f2 and D21) coated probes and solids of different surface hydrophobicity, in liquid. Both attractive forces and cell adhesion behavior were promoted by substratum surface hydrophobisity, pointing to the role of hydrophobic interactions. Interaction forces were measured between probes coated with E. coli cells and mica or polymeric membranes (Table 7).

Table 7 shows that D21f2 $\left(\theta_{\text {water }}=31^{\circ}\right)$ experienced a strong repulsive force upon approaching mica $\left(\theta_{\text {water }}=0^{\circ}\right)$ (where $\theta$ is the contact angle) and glass $\left(\theta_{\text {water }}=14^{\circ}\right)$ while D21 $\left(\theta_{\text {water }}=19^{\circ}\right)$ was attracted to both substrates. D21f2 was attracted to both polystyrene $\left(\theta_{\text {water }}=74^{\circ}\right)$ and Teflon $\left(\theta_{\text {water }}=110^{\circ}\right)$ while D21 displaced a net repulsion for both substrates. Upon addition of $\mathrm{NaCl}$ to the buffer, the repulsion between D21f2 and mica was reduced, while the attraction between D21 and mica remained identical to the attraction observed in buffer without NaCL. Therefore, the repulsive force between D21f2 and mica is electrostatic in nature. On the hydrophobic glass surface OTS-glass $\left(\theta_{\text {water }}=95^{\circ}\right)$ both bacterial strains experienced attractive forces while by the clean, hydrophilic glass
Table 5. Tip-surface adhesion forces on cell surface, at cell-cell interface and at cell-substratum periphery (Fang et al., 2000)

\begin{tabular}{l|l|l|l}
\hline Time $(\mathrm{h})$ & Bacteria Surface $(\mathrm{nN})$ & $\begin{array}{l}\text { Cell-Substratum Periphery } \\
(\mathrm{nN})\end{array}$ & $\begin{array}{l}\text { Cell-Cell Interface } \\
(\mathrm{nN})\end{array}$ \\
\hline 1 & $-4.07+/-0.40$ & $-5.08+-/ 0.40$ & $\mathrm{n} / \mathrm{a}$ \\
\hline 2 & $-4.08+-/ 0.47$ & $-5.37+-/ 0.60$ & $\mathrm{n} / \mathrm{a}$ \\
\hline 4 & $-4.25+/-/ 0.39$ & $-5.88+-/ 0.70$ & $\mathrm{n} / \mathrm{a}$ \\
\hline 8 & $-4.10+-/ 0.31$ & $\mathrm{n} / \mathrm{a}$ & $-6.81+-/ 0.53$ \\
\hline 12 & $-3.87+-/ 0.74$ & $\mathrm{n} / \mathrm{a}$ & $-6.49+-/ 0.52$ \\
\hline 36 & $-3.96+-/ 0.39$ & $\mathrm{n} / \mathrm{a}$ & $-6.78+-/ 0.77$ \\
\hline
\end{tabular}

Table 6. Tip-E.coli on glass interaction forces (Razatos et al., 1998)

\begin{tabular}{c|c|c}
\hline $\begin{array}{l}\text { Separation } \\
\text { Distance }(\mathrm{nm})\end{array}$ & D21f2/glass (nN) & D21/glass (nN) \\
\hline 2 & 0.285 & -0.265 \\
\hline 11 & 0.12 & -0.02 \\
\hline 21 & 0 & 0 \\
\hline
\end{tabular}

D21f2 was mildly repelled and D21 weakly attracted.

Although, for hydrophilic surfaces at large distances of separation and for D21f2 the DLVO theory agrees with experimental results, the DLVO theory does not agree with the experimental results for D21 (Fig. 20). One reason for the discrepancy between theory and experimental data may be due to steric, solvation or other specific short-range interactions, which become important at small separation distances. Figure 20 shows the computed force versus distance curves for polystyrene with and without accounting for steric effects. The inclusion of steric interactions leads to an additional repulsive component for D21. The interaction force is modulated, resulting in a net repulsion, which is consistent with experimental observations for D21. For D21f2, however, it is seen that the addition of steric interactions still gives rise to a net attraction to the polymer. Therefore, the augmented DLVO model incorporating both hydrophobic and steric interactions was developed to model bacterial adhesion as monitored by AFM. This model was found to qualitatively agree with experimental observations. Other factors such as bridging effects or specific receptor-ligand interactions will need to be accounted for in detail.

However, the above approach is limited by the need to use a physicochemical treatment in order to firmly anchor the cells to the probe, this procedure may alter the cell surface properties, and by the impossibility to exploit the high lateral resolution of AFM for mapping interaction forces and controlling surface morphology.

In all the above cases, interaction forces between bacterial cells and surfaces are measured, but no

Table 7. Modified tip-material interaction forces (Ong et al., 1999)

\begin{tabular}{l|l|l|l|l|l|l|l|l|l|l|l|l}
\hline $\begin{array}{l}\text { Separ. } \\
\text { Distance } \\
(\mathrm{nm})\end{array}$ & $\begin{array}{l}\text { Glass } \\
\mathrm{D} 21 \mathrm{f} 2 \\
(\mathrm{nN})\end{array}$ & $\begin{array}{l}\text { Glass } \\
/ \mathrm{D} 21 \\
(\mathrm{nN})\end{array}$ & $\begin{array}{l}\text { Mica } \\
\mathrm{D} 21 \mathrm{f} 2 \\
(\mathrm{nN})\end{array}$ & $\begin{array}{l}\text { Mica } \\
/ \mathrm{D} 21 \mathrm{f} 2 \\
+\mathrm{NaCl} \\
(\mathrm{nN})\end{array}$ & $\begin{array}{l}\text { Mica } \\
\mathrm{D} 21 \\
(\mathrm{Nn})\end{array}$ & $\begin{array}{l}\text { Mica } \\
/ \mathrm{D} 21+ \\
\mathrm{NaCl} \\
(\mathrm{nN})\end{array}$ & $\begin{array}{l}\text { OTS- } \\
\text { Glass } \\
/ \mathrm{D} 21 \mathrm{f} 2 \\
(\mathrm{nN})\end{array}$ & $\begin{array}{l}\text { OTS- } \\
\text { Glass } \\
/ \mathrm{D} 21 \\
(\mathrm{nN})\end{array}$ & $\begin{array}{l}\text { PS } \\
/ \mathrm{D} 21 \mathrm{f} 2 \\
(\mathrm{nN})\end{array}$ & $\begin{array}{l}\text { PS } \\
/ \mathrm{D} 21 \\
(\mathrm{nN})\end{array}$ & $\begin{array}{l}\text { Teflon } \\
/ \mathrm{D} 21 \\
(\mathrm{nN})\end{array}$ & $\begin{array}{l}\text { Teflon } \\
/ \mathrm{D} 21 \\
(\mathrm{nN})\end{array}$ \\
\hline 0 & 0.65 & -0.03 & 0.65 & 0.58 & -0.97 & -1 & -23 & -10 & -0.38 & 0.53 & -0.8 & -0.06 \\
\hline 10 & 0.19 & -0.6 & 0.19 & 0.65 & -0.19 & -0.55 & -21 & -7 & -0.12 & 0.06 & -0.46 & 0 \\
\hline 20 & 0.06 & 0 & 0.06 & 0.35 & 0 & 0 & -17 & -4 & 0 & 0 & -0.06 & 0 \\
\hline
\end{tabular}


detachment forces can be measured. For this reason, two variations of the AFM technique as force sensing have been used. The first one by Yamamoto et al. (1998) utilizes a microcantilever to measure the detachment force of a cell that has adhered to a material (Fig. 21a). As the cell adheres to a material in a medium, the XY-stage of the microscope is been moved at a constant velocity. When the tip of the microcantilever touches the cell, a lateral load is applied to it and the cantilever is deflected corresponding to the deformation of the cell and the required shear force to detach the cell from the material.

The deflection of the cantilever is measured and the shear force applied to the cell, F, is calculated by Equation. (4):

$$
\mathrm{F}=\mathrm{k} * \delta 1
$$

Where $\mathrm{k}$ is the force spring constant of the cantilever and $\delta 1$ is the deflection of the cantilever. The shear force applied to the cell is recorded as a function of the displacement of the XY-stage and thus graphs like that in Figure 22 are generated. The required shear force to detach the cell is equal to the maximum force that appears in the forcedisplacement curves. The integrated area underneath the curve is supposed to be the total energy necessary to detach the cell from the materials. Experiments using this technique have been done with murine fibroblasts and shear forces of detachment in the range from 300 to 500 $\mathrm{nN}$ have been reported.

The second variation (Sagvolden et al., 1999) involves the use of an inclined atomic microscope cantilever and the laser beam deflection to measure the force. The set up is shown schematically in Figure 21b. The substrate moves at a constant velocity so that the cell is displaced and when it touches the tip of the cantilever the force on the cell increases. Gradually the cell is released from the surface and finally it is moved freely as the last bond is broken. The required force is recorded by the cantilever deflection with the help of a laser beam and a CCD array. During the experiment the typical force-displacement curve is recorded and the detachment force and energy is calculated. Experiments with this technique have been done with silica microspheres coated with glutaraldehyde and with cervical carcinoma cells cultured in hydrophobic or hydrophilic polystyrene substrates. Typical values of the detachment force have been measured in the range from 20 to $200 \mathrm{nN}$.

\section{Discussion}

All the above techniques provide us with an impressive array of tools for investigating bacteria-material interactions in vitro. Each one has certain advantages and disadvantages with respect to the others based on the sophistication of the equipment, the cost, the calibration of the force transducers, especially in the lower range, the optical observation, the non-disturbance of the bacteria under investigation etc.

In global tests, (static assays, flow chambers, rotating disc) where populations of bacteria are involved, a formidable problem is that of the existence of subpopulations of bacteria with stochastic adhesive

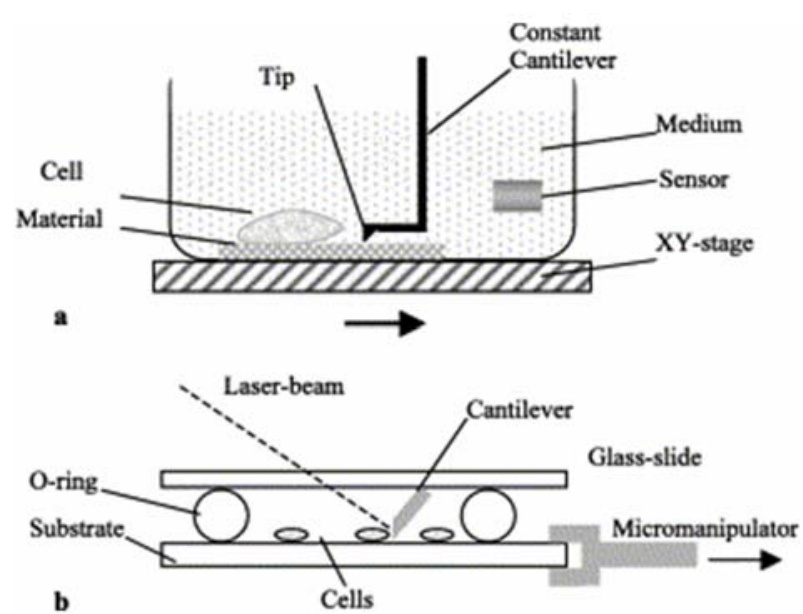

Figure 21. (a) A simplified schematic of the principle of measurement of a cell detachment with the use of shear force (Yamamoto et al., 1998). (b) A schematic experimental set-up of a manipulation force microscope, which employs an inclined microcantilever and a laser beam deflection to measure the force (Sagvolden et al., 1999).

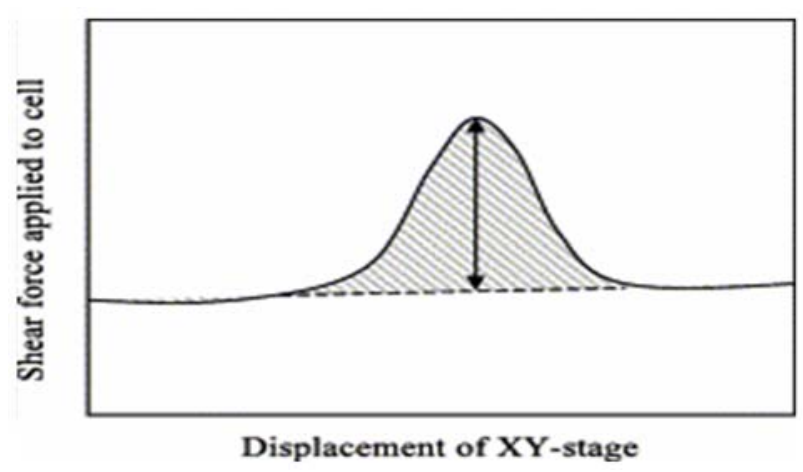

Figure 22. A schematic force-displacement curve. The cell detachment shear force is defined as the maximum force (Yamamoto et al., 1998).

expression and of the uncertainty of the various degrees of adhesion of individual bacteria. For this reason, lately, probabilistic approaches attempt to characterize more accurately the attachment/detachment process. On the other hand, in single cell manipulation experiments, Monte Carlo simulations have been applied to understand the stochastic kinetics of the receptor-ligand bonds.

In all these techniques, the assumptions of the underlying mechanisms of the bacteria approaching the surface, the kinetics of receptor expression, the generation of focal adhesion points, the hypothesis regarding bond formation and breakage, and the number of specific receptors for the corresponding ligands add to the approximate nature of such investigations. In addition, the lack of a standard experimental procedure does not help in the impartial comparison of the techniques.

Measuring interaction forces using the AFM has the advantage of using a reliable device, however, the possible destructive deformation of bacteria due to the geometry of the tip is of concern and maybe a source for the observed variation of results. Moreover, the need to use a 
physicochemical treatment in order to firmly anchor the cells to the probe may alter the cell surface properties, leading to false results.

Therefore, since the molecular and physical interactions that govern bacterial adhesion to biomaterials have not been understood in detail all the available preventive measures that decrease the rate of bacterial infections should be taken. These preventive strategies could be: experienced therapy teams to insert and maintain indwelling devices, maximum sterile barriers, such as sterile gloves, masks, gowns, caps, large drapes and careful handwashing. Use of these precautions has been linked to a four-fold decrease in the rate of bacteriaemia. Moreover, cutaneous antimicrobials and antiseptics, ionic silver cuffs, combination of antibiotics with heparin, antiseptic hubs and antimicrobial coatings of biomaterial surfaces have shown good results against microbial colonization and produced bacteriaemia, especially when the right antibiotics are chosen against each type of bacteria.

\section{Concluding Remarks}

A large amount of research work has been done and great achievements have been made in understanding the mechanisms of bacterial adhesion and prosthetic infection. However, since bacterial adhesion is a very complicated process affected by many factors, such as bacterial-material properties, environment, and, furthermore the experimental evaluation of the relative contributions of these factors is extremely difficult, more investigations are still needed to advance our understanding of the mechanisms of bacterial adhesion and prosthetic infection, and to attain appropriate methods to prevent them from happening. Most of the studies so far have utilized: different materials (glass, metals, polymers), different bacterial strains-species and concentrations, different experimental procedures (static, flow, AFM, time, environment). Polymer systems used in biointeraction studies do not allow for systematiccontrolled variations in material surface properties. Surface chemical modification often leads to surface heterogeneity and increased roughness, trace impurities, in many polymers used, result in uncertainties. Therefore, a rigorous study of the effects of surface chemistry/topography on bacterial adhesion and protein adsorption requires a model system that allows precise control of the type and the configuration of functional groups at the substratum surface under dynamic conditions. All the techniques mentioned here, although they cannot be used routinely in the clinical field because of the cost, the complexity of the set up and the time they need in order to give results, they are necessary in the research field of quantitative definition of bacteria-material interactions.

\section{References}

Alfonso JL, Goldmann WH (2003) Feeling the forces: atomic force microscopy in cell biology. Life Sci 72: 2553 2560 .

An YH, Friedman RJ (1997) Laboratory methods for studies of bacterial adhesion. J Microbiol Meth 30: 141152.
An YH, Friedman RJ (1998) Concise review of mechanisms of bacterial adhesion to biomaterial surfaces. J Biomed Mater Res (Appl Biomater) 43: 338-348.

Arciola CR, Campoccia D, Montanaro L (2002) Effects of antibiotic resistance of Staphylococcus epidermidis following adhesion to polymethylmethacrylate and to silicone surfaces. Biomaterials 23: 1495-1502.

Bakker DP, Huijs FM, DeVries J, Klijnstra JW, Busscher JH, van der Mei HC (2003) Bacterial deposition to fluoridated and non-fluoridated polyurethane coatings with different elastic modulus and surface tension in a parallel plate and a stagnation point flow chamber. Col Surf B: Biointerf 32: 179-190.

Balazs DJ, Triandafillu K, Chevolot Y, Aronsson BO, Harms H, Descouts P, Mathieu HJ (2003) Surface modification of PVC endotracheal tubes by oxygen glow discharge to reduce bacterial adhesion. Surf Interf Anal 35: 301-309.

Baumgartner JN, Cooper SL (1998) Influence of thrombus components in mediating staphylococcus aureus adhesion to polyurethane surfaces. J Biomed Mater Res 40: $660-670$.

Baveja JK, Willcox MDP, Hume EBH, Kumar N, Odell R, Poole-Werner LA (2004) Furanones as potential antibacterial coatings on biomaterials. Biomaterials 25: 50035012.

Beech IB, Smith JR, Steele AA, Penegar I, Campbell SA(2002) The use of atomic force microscopy for studying interactions of bacterial biofilms with surfaces. Coll Surf B: Biointerf 23: 231-247.

Bolshakova AV, Kiselyova OI, Filonov AS, Frolova OY, Lyubchenko YL, Yaminsky IV (2001) Comperative studies of bacteria with an atomic force microscopy operating in different modes. Ultramicrosc 86: 121-128.

Bos R, van der Mei HC, Gold J, Busscher HJ (2000) Retention of bacteria on a substratum surface with micropatterned hydrophobicity. FEMS Microbiol Let 189: 311 315.

Bowen R, Hilal N, Lovitt RW, Wright CJ (1998) Direct measurements of a force of adhesion of a single biological cell using an atomic force microscope. Col Surf A: Physicochem Eng Asp 136: 231-234.

Boyd RD, Verran J, Jones MV, Bhakoo M (2002) Use of Atomic Force Microscope to determine the effect of substratum surface topography on bacterial adhesion. Langmuir 18: 2343-2346.

Bruinsma GM, van der Mei HC, Busscher HJ (2001) Bacterial adhesion to surface hydrophilic and hydrophobic contact lenses. Biomaterials 22: 3217-3224.

Buczynski BW, Kory MM, Steiner RP, Kittinger TA, Ramsier RD (2003) Bacterial adhesion to zirconium surfaces. Col Surf B: Biointerf 30: 167-175.

Bunt CR, Jones DS, Tucker IG, (1993) The effects of $\mathrm{pH}$, ionic strength and organic phase on the bacterial adhesion to hydrocarbons (BATH) test. Intern J Pharm 99: 93-98.

Bunt CR, Jones DS, Tucker IG, (1995) The effects of $\mathrm{pH}$, ionic strength and polyvalent ions on the cell surface hydrophobicity of Escherichia coli evaluated by the BATH and HIC methods. Intern J Pharm 113: 257-261. 
Chang HT, Rittmann BE, Amar D, Heim R, Ehrlinger O, Lesty Y (1991) Biofilm detachment mechanisms in a liquid fluidised bed. Biotechnol Bioeng 38: 499-506.

Chang CC, Merritt K (1992) Microbial adherence on poly(methyl methacrylate) (PMMA) surfaces. J Biomed Mater Res 26: 197-207.

Christensen GD, Baldassarri L, Simpson WA (1994) Colonization of medical devices by coagulase-negative staphylococci". In: Infections Associated with Indwelling Medical Devices, 2nd edition. Bisno AL, Waldvogel FA (eds). American Society for Microbiology, Washington, DC. Chapter 5,

Cordero J, Munuera L, Folgueira MD (1996) The influence of the chemical composition and surface of the implant on infection. Injury 27: S-C34-37.

Costerton JW (1999) Introduction to biofilm. Intern J Antimicrob Agents 11: 217-221.

C osterton JW, Stewart PS, Greenberg EP (1999) Bacterial biofilms: a common cause of persistent infections. Science 284: 1318-1322.

Davenas J, Thevenard P, Philippe F, Arnaud MN, (2002) Surface implantation treatments to prevent infection complications in short term devices. Biomol Eng 19: 263 268.

DeJong P TeGiffel MC, Kiezebrink EA, (2002) Prediction of the adherence, growth and release of microorganisms in production chains. Intern $\mathrm{J}$ Food Microbiol 74: 13-25.

Dickinson RB, Cooper SL (1995) Analysis of sheardependent bacterial adhesion kinetics to biomaterial surfaces. Bioeng Food Nat Prod 41: 2160-2174.

Dickinson RB, Nagel JA, McDevitt D, Foster TJ, Proctor RA, Cooper SL (1995) Quantitative comparison of clumping factor- and coagulase mediated Staphylococcus aureus adhesion to surface-bound fibrinogen under flow. Infect Immun 63: 3143-3150.

Dickinson RB, Nagel JA, Proctor RA, Cooper SL (1997) Quantitative comparison of shear-dependent Staphylococcus aureus adhesion to three polyurethane ionomer analogs with distinct surface properties. J Biomed Mater Res 36: 152-162.

Diekema DJ, Pfaller MA, Schmitz FJ (2001) Survey of infections due to staphylococcus species: frequency of occurrence and antimicrobial susceptibility of isolates collected in the United States, Canada, Latin America, Europe and the Pacific region for the Sentry antimicrobial surveillance program, 1997-1999. Clin Infect Dis 32: 114132.

Donlan RM, Costerton JW (2002) Biofilms: survival mechanisms of clinically relevant microorganisms. Clin Microb Reviews 15: 167-193.

Duddridge JE, Kent CA, Laws JF (1982) Effect of surface shear stress on the attachment of Pseudomonas fluorescens to stainless steel under defined flow conditions. Biotechnol Bioeng XXIV: 153-164.

Dufrene YF (2001) Application of Atomic Force Microscopy to microbial surfaces: from reconstituted cell surface layers to living cells. Micron 32: 153-165.

Dufrene YF (2002) Atomic Force Microscopy: a powerful tool in Microbiology. J Bacteriol 184: 5205-5213.
Dufrene YF (2003) Recent progress in the application of atomic force microscopy imaging and force spectroscopy to microbiology. Cur Opin In Microbiol 6: 317-323.

Duguid IG, Evans E, Brown MR, Gilbert P (1992) Effect of biofilm culture upon the susceptibility of Staphylococcus epidermidis to tobramycin. J Antimicrob Chemother 30: 803-810.

Edwards KJ, Rutenberg AD (2001) Microbial response to surface microtopography: the role of metabolism in localized mineral dissolution. Chem Geol 180: 19-32.

Fallgren C, Ljungh A, Shenkman B, Varon D, Savion N (2002) Venous shear stress enhances platelet mediates staphylococcal adhesion to artificial and damaged biological surfaces. Biomaterials 23: 4581-4589.

Fang HHP, Chan K-Y, Xu L-C (2000) Quantification of bacterial adhesion forces using atomic force microscopy. J Microbiol Meth 40: 89-97.

Flemming RG, Capelli CC, Cooper SL, Proctor RA (2000) Bacterial colonization of functionalized polyurethanes. Biomaterials 21: 273-281.

Fletcher M, Marshall KC (1982) Bubble contact angle method for evaluating substratum interfacial characteristics and its relevance to bacterial attachment. Appl Environ Microbiol 44:184-192.

Francois P, Vaudaux P, Nurdin N, Mathieu HJ, Descouts P, Lew DP (1996) Physical and biological effects of a surface coating procedure on polyurethane catheters. Biomaterials 17: 667-678.

Garcia-Saenz MC, Arias-Puente A, FresnadilloMartinez MJ, Matilla-Rodriguez A (2000) In vitro adhesion of Staphylococcus epidermidis to intraocular lenses. J Cataract Refract Surg 26: 1673-1679.

Geesey GG (2001) Bacterial behaviour at surfaces. Cur Opin In Microbiol 4: 296-300.

Gottenbos B, van der Mei HC, Busscher HJ (2000) Initial adhesion and surface growth of Staphylococcus epidermidis and Pseudomonas aeruginosa on biomedical polymers. J Biomed Mater Res 50: 208-214.

Gottenbos B, Busscher HJ, Van Der Mei HC, Nieuwenhuis P (2002) Pathogenesis and prevention of biomaterial centered infections. J Mat Sci: Mat In Med 13: $717-722$.

Gotz F (2002) Staphylococcus and biofilms. Mol Microb 43: 1367-1378.

Gray ED, Peters G, Verstegen M, Regelmann WE (1984) Effect of extracellular slime substance from Staphylococcus epidermidis adhesion on human cellular immune response. Lancet 18: 365-367.

Harris LG, Tosatti S, Wieland M, Textor M, Richards RG (2004) Staphylococcus aureus adhesion to titanium oxide surfaces coated with non-functionalized and peptidefunctionalized poly (L-lysine)-grafted-poly(ethylene glycol) copolymers. Biomaterials 25: 4135-4148.

Hauert R (2003) A review of modified DLC coatings for biological applications. Diam Rel Mater 12: 583-589.

Heilmann C, Schweitzer O, Gerke C, Vanittanakom N, Mack D, Gotz F (1996) Molecular basis of intercellular adhesion in the biofilm-forming Staphylococcus epidermidis. Mol Microbiol 20: 1083-1091. 
Henriques M, Azeredo J, Oliveira R (2004) Adhesion of Candida albicans and Candida dubliniensis to acrylic and hydroxyapatite. Col Surf B Biointerf 33: 235-241.

Hermansson M (1999) The DLVO theory in microbial adhesion. Coll Surf B: Biointerf 14: 105-119.

Herrmann M, Vaudaux PE, Pittit D (1988) Fibronectin, fibrinogen, and laminin act as mediators of adherence of clinical staphylococci isolates to foreign material. J Infect Dis 158: 693-701.

Hubble J, Ming F, Eisenthal R, Whish W (1996) Progressive detachment of cells from surfaces: a consequence of heterogeneous ligand populations or a multi-site binding equilibrium? J Theor Biol 182: 169171.

Hubble J (2003) Monte Carlo simulation of biospecific interactions between cells and surfaces. Chem Eng Sci 58: 4465-4474.

Huebner J, Goldmann DA (1999) Coagulase-negative staphylococci: role as pathogens. Ann Rev Med 50: 223 226.

Isberg RR, Barnes P (2002) Dancing with the host: flow-dependent bacterial adhesion. Cell 110: 1-4

James NR, Jayakrishnan A (2003) Surface thiocyanation of plasticized poly(vinyl chloride) and its effect on bacterial adhesion. Biomaterials 24: 2205-2212.

Jansen B, Hartmann C, Schumacher-Perdreau F, Peters G (1991) Late onset endophthalmitis associated with intraocular lens: a case of molecularly proved $S$. epidermidis aetiology. Br J Ophthalml 75: 440-441.

Jenal U (2004) Cyclic di-guanosine-monophosphate comes of age: a novel secondary messenger involved in modulating cell surface structures in bacteria? Cur Opin Microbiol 7: 185-191.

Jucker BA, Zehnder AJB, Harms H (1998) Quantification of polymer interactions in bacterial adhesion. Environ Sci Technol 32: 2909-2915.

Karamanos NK, Panagiotopoulou HS, Syrokou A, Frangides C, Hjerpe A, Dimitrakopoulos G, Anastassiou ED (1995) Identity of macromolecules present in the extracellular slime layer of Staphylococcus epidermidis. Biochimie 77: 217-224.

Kiremitci-Gumustederelioglu M, Pesmen A (1996) Microbial adhesion to ionogenic PHEMA, PU and PP implants. Biomaterials 17: 443-449.

Kirov SM (2003) Bacteria that express lateral fragella enable dissection of the multifunctional roles of fragella in pathogenesis. FEMS Microbiol Let 224: 151-159.

Klapper I, Rupp CJ, Cargo R, Purvedorj B, Stoodley P (2002) Viscoelastic fluid description of bacterial biofilm material properties. Biotech Bioeng 80: 289-296.

Kohnen W, Kolbenschlag C, Teske-Keiser S, Jansen B (2003) Development of a long-lasting ventricular catheter impregnated with a combination of antibiotics. Biomaterials 24: 4865-4869.

Krimer V, Merkert H, Von Eiff C, Frosch M, Eulert J, Lohr JF, Hacker J, Ziebuhr W (1999) Detection of Staphylococcus aureus and Staphylococcus epidermidis in clinical samples by $16 \mathrm{~S}$ rRNA-directed in situ hybridisation. J Clin Microbiol 37: 2667-2673.

Kuusela P, Vartio T, Vuento M, Myhre EB (1985) Attachment of staphylococci and streptococci on fibronectin, fibronectin fragments, and fibrinogen bound to a solid phase. Infect Immunol 50: 77-85.

Lejeune P (2003) Contamination of abiotic surfaces: what a colonizing bacterium sees and how to blur it. Trend in Microbiol 11: 179-184.

Liu Y, Tay J-H (2001) Metabolic response of biofilm to shear stress in fixed-film culture. J Appl Microbiol 90: 337-342.

Liu Y, Tay J-H (2002) The essential role of hydrodynamic shear force in the formation of biofilm and granular sludge. Water Res 36: 1653-1665.

Lower SK, Tadanier CJ, Hochella MF (2000) Measuring interfacial and adhesion forces between bacteria and mineral surfaces with biological force microscopy Geochim Cosmochim Acta 64: 3133-3139.

Mack D (1999) Molecular mechanisms of Staphylococcus epidermidis biofilm formation. J Hosp Inf 43: S113-S125.

Mah T-FC, O’Toole GA(2001) Mechanisms of biofilm resistance to antimicrobial agents. Trends in Microbiol 9: 34-39.

Maki DG, Stolz SM, Wheeler S, Mermel LA (1997) Prevention of central venous catheter-related bloodstream infection by use of an antiseptic-impregnated catheter: a randomised, controlled trial. Ann Intern Med 127: 257266.

Mascari L, Ymele-Leki P, Eggleton CD, Speziale P, Ross JM (2003) Fluid shear contributions to bacteria cell detachment initiated by a monoclonal antibody. Biotechnol Bioeng 83: 65-74.

Mayer C, Moritz R, Kirschner C, Borchard W, Maibaum R, Wingender J, Flemming H-C (1999) The role of intermolecular interactions: studies on model systems for bacterial biofilms. Intern J Biol Macromol 26: 3-16.

McWhirter MJ, McQuillan AJ, Bremer PJ (2002) Influence of ionic strength and $\mathrm{pH}$ on the first $60 \mathrm{~min}$ of Pseudomonas aeruginosa attachment to $\mathrm{ZeSe}$ and to $\mathrm{TiO}_{2}$ monitored by ATR-IR spectroscopy. Col Surf B: Biointerf 84: 17-25.

Medilanski E, Kaufmann K, Wick L, Wanner O, Harms $\mathrm{H}$ (2002) Influence of surface topography of stainless steel on bacterial adhesion. Biofoul 18: 193-203.

Merriam CV, Fernandez HT, Citror DM, Tyrrell KL, Warren YA, Goldstein EJC, (2003) Bacteriology of human bite wound infections". Anaerobe 9: 83-86.

Miele PS, Kogulan PK, Levy CS (2001) Seven cases of surgical native valve endocarditis caused by coagulasenegative staphylococci: an underappreciated disease. Am Heart J 142: 571-576.

Ming F, Whish W, Hubble J, Eisenthal R (1998) Estimation of parameters for cell-surface interactions: maximum binding force and detachment constant. Enzyme Microbiol Technol 22: 94-99.

Miorner H, Myhre E, Bjorck L, Kronvall G (1980) Effect of specific binding of human albumin, fibrinogen, and immunoglobulin $\mathrm{G}$ on surface characteristics of bacterial strains as revealed by partition experiments in polymer phase system. Infect Immunol 29: 879-885.

Missirlis YF, Spiliotis AD (2002) Assessment of techniques used in calculating cell-materials interactions. Biomolec Engin 19: 287-294. 
Mohamed N, Rainier TR, Ross JM (2000) Novel experimental study of receptor-mediated bacterial adhesion under the influence of fluid shear. Biotechnol Bioeng 68: 628-636.

Monzón M, Concepción Oteiza C, Leiva J, Lamata M, Amorena B (2002) Biofilm testing of Staphylococcus epidermidis clinical isolates: low performance of vancomycin in relation to other antibiotics. Diagn Microbiol Infect Dis 44: 319-324.

Morra M, Cassinelli C (1996) Staphylococcus epidermidis adhesion to films deposited from hydroxyethylmethacrylate plasma. J Biomed Mater Res 31: 149-155.

Morra M, Cassinelli C (1997) Bacterial adhesion to polymer surfaces: A critical review of surface thermodynamic approaches. J Biomater Sci Polymer Edn 9: $55-74$.

Moter A, Gobel UB (2000) Fluorecence in situ hybridization (FISH) for direct visualization of microorganisms. J Microbiol Meth 41: 85-112.

O’Gara JP, Humphreys H (2001) Staphylococcus epidermidis biofilms: importance and implications. J Med Microbiol 50: 582-587.

O'Toole G, Kaplan HB, Kolter R (2000) Biofilm formation as microbial development. Ann Rev Microbiol 54: 49-79.

Ong Y-L, Razatos A, Georgiou G, Sharma MM (1999) Adhesion forces between $E$. coli bacteria and biomaterial surfaces. Langmuir 15: 2719-2725.

Pagano L, Tacconelli E, Tumbarello M, (1997) Bactaraemia in patients with hematological malignancies. Analysis of risk factors, etiological agents and prognostic indicators. Haematologica 82: 415-419.

Paragioudaki M, Stamouli V, Kolonitsiou F, Anastassiou ED, Dimitrakopoulos G, Spiliopoulou I (2004) Intravenous catheter infections associated with bacteraemia: a 2-year study in a University Hospital. Eur Soc Clin Microbiol Infect Dis 10: 431-435.

Park KD, Kim YS, Han DK, Kim YH, Lee EHB, Suh H, Choi KS (1998) Bacterial adhesion on PEG modified polyurethane surfaces. Biomaterials 19: 851-859.

Paulsson M, Gouda I, Larm O, Ljungh A (1994) Adherence of coagulase-negative staphylococci to heparin and other glucosaminoglycans immobilized on polymer surfaces. J Biomed Mater Res 28: 311-317.

Perdreau-Remington F, Stefanik D, Peters G (1996) A four-year prospective study on microbial ecology of explanted prosthetic hips in 52 patients with aseptic prosthetic joint loosening. Eur J Clin Microbiol Infect Dis 15: $160-165$.

Pessoa-Silva CL, Miyasaki CH, De Almeida MF, Kopelman BI, Raggio RL, Wey SB (2001) Neonatal lateonset bloodstream infection: attributable mortality, excess of length of stay and risk factors. Eur J Epidemiol 17: 715-720.

Peters G, Locci R, Pulverer G (1982) Adherence and growth of coagulase-negative staphylococci on surfaces of intravenous catheters. J Infect Dis 146: 479-482.

Raad I (1998) Intravascular-catheter-related infections. Lancet 351: 893-898.
Razatos A, Ong Y-L, Sharma MM, Georgiou G (1998) Evaluating the interaction of bacteria with biomaterials using atomic force microscopy. J Biomater Sci Polym Edn 9: 1361-1373.

Rijnaarts HHM, Norbe W, Bouwer EJ, Lyklema J, Zehnder AJB (1995) Reversibility and mechanism of bacterial adhesion. Col Surf B: Bioint 4: 5-22.

Robichon D, Girard J-C, Cenatiempo Y, Cavallier J-F (1999) Atomic force microscopy imaging of dried or living bacteria. C R Acad Sci Paris, Life Sci 322: 687-693.

Rupp ME, Archer GD (1994) Coagulase-negative staphylococci: pathogenesis associated with medical progress. Clin Infect Dis 19: 231-245.

Sagvolden G, Giaever I, Pettersen EO, Feder J (1999) Cell adhesion force microscopy Proc Natl Acad Sci USA 96: 471-476.

Sanderson NM, Guo B, Jacob AE, Handley PS, Cunniffe JG, Jones MN (1996) The interaction of cationic liposomes with the skin-associated bacterium Staphylococcus epidermidis: effects of ionic strength and temperature. Biochim Bioph Acta (BBA) - Biomembr 1283: $207-214$.

Scheuerman TR, Camper AK, Hamilton MA (1998) Effects of substratum topography on bacterial adhesion. J Col Interf Sci 208: 23-33.

Schierholz JM, Beuth J, Pulverer G (2000) Evidence for a self-fulfilling hypothesis: chlorhexidine dressing for reduction of microbial colonization of the skin with central venous catheters. J Hosp Infect 44: 241-242.

Scierholz JM, Beuth J (2001) Implant infections: a haven of opportunistic bacteria. J Hosp Infect 49: 87-93.

Shi L, Ardehali R, Caldwell KD, Valint P (2000) Mucin coating on polymeric material surfaces to suppress bacterial adhesion. Col Surf B: Biointerf 17: 229-239.

Silver S (2003) Bacterial silver resistance: molecular biology and uses and misuses of silver compounds. FEMS Microbiol Rev 27: 341-353.

Souvenir D, Anderson DEJ, Palpant S, Mroch H, Askin S, Anderson J, Claridge J, Eiland J, Malone C, Garrison MW, Watson P, Cambell DM (1998) Blood cultures positive for coagulase-negative staphylococci: antisepsis, pseudobacteraemia and therapy of patients. J Clin Microbiol 36: 1923-1926.

Speranza G, Gottardi G, Pederzolli C, Lunelli L, Canteri R, Pasquardini 1, Carli E, Lui A, Mniglio D, Brugnara M, Anderle M (2004) Role of chemical interactions in bacterial adhesion to polymer surfaces". Biomaterials 25: 20292037.

Stewart PS, Costerton JW (2001) Antibiotic resistance of bacteria in biofilms. Lancet 358: 135-138.

Stoodley P, Lewandowski Z, Boyle JD, Lappin-Scott HM (1999) Structural deformation of bacterial biofilm caused by short-term fluctuations in fluid shear: an in situ investigation of biofilm rheology. Biotechnol Bioeng 65: 83-92.

Tacconelli E, Tumbarello M, Pittiruti M, Leone F, Lucia MB, Cauda R, Ortona L (1997) Central venous catheterrelated sepsis in a cohort of 366 hospitalised patients. Eur J Clin Microbiol Infect Dis 16: 203-209. 
Taylor RL, Verran J, Lees GC, Ward AJP (1998) The influence of substratum topography on bacterial adhesion to polymethyl methacrylate. J Mater Sci: Mater Med 9: 17-22.

Tegoulia VA, Cooper SL (2002) Staphylococcus aureus adhesion to self-assembled monolayers: effect of surface chemistry and fibrinogen presence. Col Surf B: Biointerf 24: 217-228.

Trautner BW, Darouicher. O (2004) Role of biofilm in catheter-associated urinary tract infection. Am J Inf Contr 32: 177-183.

Vacheethasanee K, Marchant RE (2000) Surfactant polymers designed to suppress bacterial (Staphylococcus epidermidis) adhesion on biomaterials. J Biomed Mater Res 50: 302-312.

Vacheethasanee K, Temenoff JS, Higashi JM, Gary A, Anderson JM, Bayston R, Marchant RE (1998) Bacterial surface properties of clinically isolated staphylococcus epidermidis strains determine adhesion on polyethylene. J Mater Res 42: 425-432.

Van Loosdrecht MCM, Lyklema J, Norde W, Schraa G, Zehnder AJB (1987) The role of bacterial cell wall hydrophobicity in adhesion. Appl Environ Microbiol 53: 1893-1897.

Vaudaux P, Yasuda H, Velazco MI, Huggler E, Ratti I (1990) Role of host and bacterial factors in modulating staphylococcal adhesion to implanted polymer surfaces. J Biomater Appl 5: 134-153.

Vaudaux PE, Waldvogel FA, Morgenthaler JJ, Nydegger UE (1984) Adsorption of fibronectin onto polymethylmethacylate and promotion of Staphylococcus aureus adherence. Infect Immunol 45: 768-774.

Vincent J-L (2003) Nosocomial infections in adult intensive-care units. Lancet 361: 2068-2077.

Von Eiff C, Peters G, Heilmann C (2002) Pathogenesis of infections due to coagulase-negative staphylococci. Lancet Infect Dis 2: 677-685.

Vuong C, Otto M (2002) Staphylococcus epidermidis infections. Microbes Infect 4: 481-489.

Whitehead KA, Colligon JS, Verran J (2004) The production of surfaces of defined topography and chemistry for microbial retention studies, using ion beam sputtering technology. Intern Biodeter Biodegrad 54: 143151.

Willcox MDP, Harmis N, Cowell B., Williams T, Holden BA (2001) Bacterial interactions with contact lenses; effects of lens material, lens wear and microbial physiology. Biomaterials 22: 3235-3247.

Willing GA, Ibrahim TH, Etzler FM, Neuman RD (2000) New approach to the study of particle-surface adhesion using atomic force microscopy. J Col Interf Sci 226: $185-188$.

Woodyard LL, Bowersock TL, Turek JJ, McCabe GP, DeFord J (1996) A comparison of the effects of several silver-treated intravenous catheters on the survival of staphylococci in suspension and their adhesion to the catheter surface. J Contr Rel 40: 23-30.

Yamamoto A, Mishima S, Maruyama N, Sumita M (1998) A new technique for direct measurement of the shear force necessary to detach a cell from a material.
Biomaterials 19: 871-879.

Zlatanova J, Lindsay SM, Leuda SH (2000) Single molecule force spectroscopy in biology using the atomic force microscopy. Progr Bioph Molec Biol 74: 37-61.

\section{Web References}

Fletcher M, Decho A (2001) Biofilms. Encyclopedia of life siences. Nature Publising Group/ www.els.net

\section{Discussion with Reviewers}

L. Harris: In the section entitled "Serum or Tissue Proteins", the author mentions vWF factor. Can the author comment in more detail on the fact $S$. aureus in particular has an adhesin that recognises vWF factor?

Authors: S. aureus has the ability to interact with and bind to several different plasma and extracellular matrix proteins such as fibrinogen, collagen, vitronectin and laminin, via protein adhesins of MSCRAMM (microbial surface components recognizing adhesive matrix molecules) family, which, in most cases are covalently anchored to the cell wall peptidoglycan. The first molecularly characterized MSCRAMMs of $S$. aureus are fibronectin-binding protein A (FnBPA), a collagen-binding protein (Can) and a fibrinogen-binding protein, clumbing factor A (ClfA) (Foster and Hook, 1998). In addition to blood and matrix proteins, S. aureus interacts with platelets (Fallgren et al., 2002). Among the factors released by platelets is von Willebrand factor (vWf), a large multifunctional glycoprotein characterized by high molecular weight multimers. Concerning bacterial proteins binding to vWf, there are only a few reports. The binding of S. aureus to vWf was first reported in 1997 (Hermann et al., 1997) and later it was shown that protein A mediates the adherence of S. aureus to vWf (Hartleib et al., 2000). In addition, a secreted $S$. aureus protein (vWbp) that binds vWf has recently been identified (Bjerketorp et al., 2002). Therefore $\mathrm{vWf}$ binds to and promotes the surface adhesion of S. aureus.

L. Harris: Have the flow chambers been used to evaluate the influence of bacterial adhesins and their effect on adhesion to different biomaterials?

Authors: Dickinson et al. $(1995,1997)$ used a radial flow chamber in order to evaluate receptor-mediated bacterial adhesion under the influence of fluid shear and they showed that bacteria-surface interactions are influenced by the presence of proteins on the substratum surface (Figs. 14 and 15). Mohamed et al. (2000) used a parallel plate flow chamber and they showed that in the case of higher number of receptors/cell, $S$. aureus adhesion to collagen coated coverslips increases between shear rates 50-300 s${ }^{1}$ and then decreases for shear rates higher than $500 \mathrm{~s}^{-1}$ (Fig. 5). However, it has not been shown directly whether and how functional properties of bacterial adhesins are directly modulated by shear. To our knowledge, a directly related study of the influence of bacterial adhesins on adhesion, under the influence of flow conditions, is that 
of Thomas et al. (2002) which showed that E. coli (expressing lectin-like adhesin FimH) attachment to erythrocytes switched from loose to firm upon a 10-fold increase in shear stress, due to increased bond formation (kinetic effects) and adhesin's ability to act as a force sensor. However, direct adhesin-biomaterial surface evaluation using flow chambers has not been reported yet.

J Douglas: What progress has been made in preventing bacterial adhesion to biomaterials either by changing biomaterial surface chemistry or by incorporating antimicrobial agents?

Authors: Coatings and surface treatments have been extensively studied (see Material Surface Characteristics) and a particular interest was devoted to silver as it combines antimicrobial activity and low human toxicity. Both physicochemical methods and surface engineering techniques (surface implantation) have been used in order to produce new, antibacterial surface properties. In vitro experimental results have shown that increased material hydrophilicity, antimicrobial coatings of biomaterial surfaces and especially ionic silver, and combination of antibiotics with heparin have good results against microbial colonization and bacteriaemia. Clinical trials have shown that silver coated hemodialysis catheter offered a $42 \%$, $65 \%$ and $66 \%$ reduction in bacterial positive cultures from skin, blood and catheter tip respectively (Bambauer et al., 1998).

J Douglas: What are the problems associated with such strategies?

Authors: The main problems associated with changing biomaterial surface chemistry (surface energy) and incorporating antimicrobial agents are first of all the probable heterogeneity of the produced surface, especially when we have to deal with rough surfaces, and the probable dissociation of the thin film antimicrobial coating, especially under high shear stresses. Moreover, surface treatments are not effective for long-term applications due to surface fouling and only surface bound antimicrobial technology offers advantages for long term applications. But even then, antimicrobial coatings should be checked for their bactericidal effects since immobilized ones are not as effective as soluble ones (James and Jayakrishnan, 2003) and atomic silver has not antibacterial effects in comparison to ionic silver (Davenas et al., 2002).

\section{Additional References}

Bambauer R, Mestres P, Schiel R, Schneidewind J M, Goudjinou R, Latza R, Innlger R, Bambauer S, Shishansi $P$ (1998) Surface treated large-bore catheters with silver based coatings versus untreated catheters for extracorporeal detoxification methods. ASAIO J 44: 303-308.

Bjerketorp J, Nilsson M, Ljungh A, Flock J-I, Jacobsson K, Frykberg L (2002) A novel von Willebrand factor binding protein expressed by Staphylococcus aureus. Microbiol 148: 2037-2044.

Hartleib J, Kohler N, Dickinson R B, Chhatwal G S, Sixma J J, Hartford O M, Foster T J, Peters G, Kehrel B E, Herrmann M (2000) Protein A is the von Willebrand factor binding protein on Staphylococcus aureus. Blood 96: 21492156.

Herrmann M, Hartleib J, Kehrel B, Montgomery R R, Sixma J J, Peters G (1997) Interaction of von Willebrand factor with Staphylococcus aureus. J Infect Dis 176: 984 991.

Foster T J, Hook M (1998) Surface protein adhesins of Staphylococcus aureus. Trends Microbiol 484: 484-488.

Thomas W E, Trintchina E, Forero M, Vogel V, Sokurenko E V (2002) Bacterial adhesion to target cells enhanced by shear force. Cell 109: 913-923. 